\title{
Royal Authority in the Provinces
}

This chapter examines the ceremonial entries made by the provincial governors of France. While governors were the principal agents of royal power in the frontier regions of the kingdom, historians have largely overlooked their entries. Yet this chapter demonstrates that governors' entries were important events for urban populations. Like royal women, governors represented the person of the king; moreover, they possessed wide-ranging political powers, which urban administrations sought to harness. Governors' entries grew in frequency, size and importance from the late fifteenth century to the extent that they were almost indistinguishable from those of the king. As governors were the king's proxy and exercised authority in his name, they confirmed municipal liberties and received petitions at their entries. Urban governments used ceremonial entries to create and consolidate long-lasting relationships with these powerful brokers, who provided one of the principal conduits for the flow of patronage and influence between the court and the provinces.

The French monarchy created the position of provincial governor in the fourteenth century as a means of administering the more distant parts of the kingdom. The number of governors remained small until the later fifteenth century, when the Valois kings began to appoint them in increasing numbers as a means to consolidate the Crown's control over the frontiers of the kingdom. While there were only two governorships in 1400 (Dauphiné and Languedoc), there were ten at the end of the fifteenth century (Burgundy, Champagne, Dauphiné, Île-de-France, Guyenne, Languedoc, Normandy, Picardy, Provence and Roussillon). ${ }^{1}$ The most pronounced expansion in number of governorships occurred under Louis XI, who used these officials to curb the power of the French princes. Bernard Chevalier has shown how the governors filled the role that the princes had traditionally played in the provinces and many of the gouvernements created during the later fifteenth century (such as Burgundy or Provence) corresponded to the major later medieval princely appanages. ${ }^{2}$

1 Dauphant, Royaume, 34, 337; G. Dupont-Ferrier, Gallia regia: ou État des officiers royaux des bailliages et des sénéchaussées de 1328 à 1515, 6 vols (Paris, 1942-61), ii. 301-19; iii. 466-67. There was also, briefly, a governor of Auvergne in the $1470 \mathrm{os}$ and $1480 \mathrm{~s}$.

2 Bernard Chevalier, 'Gouverneurs et gouvernements en France entre 1450 et 1520', Francia (1980), 291-307; Jean Duquesne, Dictionnaire des gouverneurs de province sous l'ancien régime 
In short, governors were the principal agents of the king in the provinces by the late fifteenth century.

While the governorships created after 1460 lacked the full range of powers held by the governors of Languedoc and Dauphiné (which included the right to issue pardons in their own name), their authority was considerable. ${ }^{3}$ Historians have traditionally found that provincial governors had a 'vice-regal' status as a result of their extensive powers. Robert Harding argued that some governors were effectively 'surrogate kings', while Michel Antoine declared that the 'fundamental and specific mission' of the governors was to represent the person of the king. ${ }^{4}$ Recently, Léonard Dauphant has cautioned against attributing vice-regal status to the governors, writing that a governor 'can govern in his name [i.e. the king] but cannot replace him. Likewise, the duke of Bourbon is lieutenant in Languedoc, and not viceroy. ${ }^{5}$ However, contemporary documents such as royal letters make it clear that a governor did in fact rule as the king's proxy in his gouvernement. Louis XI instructed Chalôns-en-Champagne

(novembre 1315-20 février 1791) (Paris, 2002), 33; Potter, Nation State, 118; For the appanages of the fourteenth century, see: F. Autrand, 'Un essai de décentralisation: la politique des apanages dans le seconde moitié du XIV e siècle', in L'administration locale et le pouvoir central en France et en Russie (XIII ${ }^{e} X V^{e}$ siècle) (Paris, 1989), 2-26.

3 P. Dognon, Les institutions politiques et administratives du pays de Languedoc du XII siècle aux guerres de religion (Toulouse, 1895), 345-62; A. Lemonde, Le Temps de libertés en Dauphiné: l'intégration d'une principauté à la Couronne de France (1349-1408) (Grenoble, 2002), 79-80. However, Louis XII took away governors' right to pardon in their own name in the ordonnance of Blois (1499), although he augmented their powers in other ways: Vassière, Ordonnances rois de France, xxi. 177-207; Potter, Nation State, 121; idem, War and Government, 100.

4 Michel Antoine, 'Institutions françaises en Italie sous le règne de Henri II: gouverneurs et intendents', Mélanges de l'Ecole française de Rome 94 (1982), 762; Robert Harding, Anatomy of a Power Elite: The Provincial Governors of Early Modern France (London, 1978), 14. See also: Ariane Boltanski, Les ducs de Nevers et l'État royal. Genèse d'un compromis (ca 1550-ca 160o) (Geneva, 2006), 82; Brink, 'Royal Power', 55; Daniel Anzar, '“Un morceau de roi”: la imagen del gobernador de provincia en la Francia barroca', in Daniel Anzar, Guillaume Hanotin and Niels F. May, eds., À la place du roi. Vice-rois, gouverneurs et ambassadeurs dans les monarchies française et espagnole (XVI ${ }^{-}-X V I I I^{e}$ siècles) (Madrid, 2014), 151-79. For early modern governors as the representatives of the monarch, see also: Alejandro Cañeque, The King's Living Image: The Culture and Politics of Viceregal Power in Colonial Mexico (New York and London, 2004), 120-32; idem, 'El simulacro del rey', in Anzar, Hanotin and May, Vice-rois, 181-208; Gabriel Guarino, Representing the King's Splendour: Communication and Reception of Symbolic Forms of Power in Viceregal Naples (Manchester, 2010), 221-28.

5 Dauphant, Royaume, 339. 
to obey Louis de Laval (governor of Champagne) 'like our person'.6 In other words, the civic administration was to follow the governor's orders as if they came directly from the king. Moreover, by the mid-sixteenth century, French towns welcomed provincial governors as if they were welcoming the king himself. Municipal councils deployed the full range of honours customarily reserved for the monarch (including the key presentation, oath taking and canopy). If the townspeople who watched a governor's entry were not aware of his identity, they could easily be forgiven for thinking that they were looking at the king.

A governor's right to receive a ceremonial entry from the towns in his province was enshrined in his letter of provision, which was read aloud during his entries before being registered at the local parlement. ${ }^{7}$ While the growth of gouvernements meant that governors' entries became more common from the later fifteenth century, towns in Dauphiné and Languedoc already had a long tradition of staging ceremonial welcomes for their governors by this time. ${ }^{8}$ As French kings rarely visited Languedoc during the fourteenth and fifteenth centuries, the populations of towns such as Beaucaire, Béziers, Nîmes and Toulouse were more accustomed to ceremonially receiving the governor than the monarch. ${ }^{9}$ Despite the early manifestations of governors' entries in Dauphiné and Languedoc, the standard form of a provincial governor's entry only emerged as a result of the negotiations that took place across the kingdom between governors, town councils and royal officials during the late fifteenth and early sixteenth century. ${ }^{10}$

6 Vaesen and Charavay, Lettres de Louis XI, iii. 135. For his appointment, see also: DupontFerrier, Gallia regia, ii. 111.

$7 \quad$ Harding, Power Elite, 14; L.-H. Labande, ed., Correspondance de Joachim de Matignon, lieutenant général du Roi en Normandie (1516-1548) (Monaco and Paris, 1914), xxxi. For an example of these letters, see: Vaesen and Charavay, Lettres de Louis XI, iii. 134.

8 AM Nîmes LL 2; AD Tarn 4 EDT CC 149; Gaston Zeller, 'Les premiers gouverneurs d'Auvergne', Revue d'Auvergne 47 (1933), 162.

9 Harding, Power Elite, 14. Even when kings toured the Languedoc, small towns such as Beaucaire were often excluded from royal schedules. Indeed, the first monarch to enter Beaucaire was Charles IX in December 1564: Lamothe, Inventaire sommaire, Beaucaire, p. 23. As a result, governors' entries were particularly significant events for Beaucaire's population. See, for example, that of Pierre de Bourbon: Lamothe, Inventaire sommaire, Beaucaire, 3 .

10 For the entries of the governors of Languedoc in the fourteenth century, see: AM Nîmes LL 2, RR 2; Challet, 'Entrées dans la ville', 276-77. 


\section{Planning Governors' Entries}

Municipal governments outside of Dauphiné and Languedoc displayed an initial uncertainty about how to welcome their governors. In part, this doubt resulted from the Crown's failure to explicitly state how governors should be received. On 20 September 1526, Rouen's procureur du roi read out a letter from Francis I to the échevins instructing them to receive the new governor of Normandy, Louis de Brézé, with 'great honour and [with the] best reception that you can, and in the manner in which it is accustomed to do in such cases to the other governors of the regions and provinces of our kingdom.." The letter's vague instructions were of little help to Rouen's échevins as the form of governors' entries varied across the kingdom and no fixed protocol had yet been established for these ceremonies. Indeed, it took three decades of debates for Rouen to settle on an acceptable form of entry for the governors of Normandy (see below). Municipal councils' uncertainty about how to receive governors was also a product of their efforts to tread a fine line between honouring the governor and preserving the king's rights. It was imperative that urban governments did not offend the monarch by granting governors any royal honours the king wished to reserve for himself. This concern was especially important as the debate on the form of governors' entries took place during a period when the Valois monarchy was placing an increasingly strong emphasis on the majesty of kingship. By the late fifteenth century, the French Crown restricted other political authorities (including dukes and bishops) from exercising sovereign rights, such as the pardoning of prisoners, at ceremonial entries. ${ }^{12}$ Accordingly, it was crucial that towns devised entries for governors that were in line with royal expectations, especially as the king was informed about how his representatives were received. Civic administrations could win the monarch's favour by greeting governors in the appropriate manner. Châlonsen-Champagne's échevins received a letter from Charles viII thanking them for the ceremonial reception they gave the incumbent governor of Champagne, Jean d'Albret, in March $1487 .{ }^{13}$ As we saw in chapter three, obtaining the monarch's favour by granting honourable entries to his representatives could win urban communities extensive new economic and political rights.

\footnotetext{
11 AD Seine-Maritime, Am Rouen A 12, fol. 83r.

12 Neil Murphy, 'Royal grace, royal punishment: ceremonial entries and the pardoning of criminals in France, c. 1440-1560', in Jeroen Duindam et al., eds., Law and Empire: Ideas, Practices, Actors (Leiden, 2013), 307-8.

13 AC Chalôns-en-Champagne вв 5, fols. 73r, 8or; Dupont-Ferrier, Gallia regia, ii. 114-15; P. Pélicier, ed., Lettres de Charles VIII, roi de France, 5 vols (Paris, 1898-1905), i. 181.
} 
Governors were entitled to a number of royal honours at their entries. First, like the monarch, they had the right to create guild masters. For example, when Pierre de Bourbon entered Toulouse as governor of Languedoc in 1488 he created a master butcher. ${ }^{14}$ By the mid-fifteenth century, the right to create guild masters at ceremonial entries was considered to be a royal prerogative, which was conferred on the king by virtue of his coronation. ${ }^{15}$ As the monarch's direct representative, governors were entitled to exercise this sovereign power in his name. Second, as the king's substitute, governors were permitted to stay in royal residences. The governor of Picardy, Jean de Bruges, lord of La Gruuthuse, lodged at Louis XII's residence in Abbeville, while Amiens' municipal council prepared the royal residence in the city for governors to use following their entries. ${ }^{16}$ Third, governors were entitled to have their arms put on municipal gates during a ceremonial entry. For instance, the arms of Jean de Laval were placed on the gates of Nantes when he entered the town as the governor of Brittany. ${ }^{17}$ This was a sovereign right that signified lordship. Refusing to enter the French town of Bapaume during his campaign against John the Fearless in 1414, Charles vi instead had his arms painted on the town walls and gates as a display of his rule over the town. ${ }^{18}$ Fourth, governors were offered town keys at their entries, which, as a mark of sovereignty, was an honour typically reserved for kings. As the governor was the king's surrogate, French town councils considered themselves to be handing over their keys to the monarch via the hands of his governor. Hence, there was a straightforward transference

14 Dauphant, Royaume, $35^{2}$.

15 Bryant, King and the City, 28-29; M. Gaillard, 'Notice d'un registre du Trésor des chartes', Mémoires de littérature de l'Académie royale des inscriptions et belles lettres 43 (1786), 676-77. When Louis XI entered Amiens in 1464, he appointed Jean Delabare to the postion of master hosier and Pierre Andras to that of master locksmith: AM Amiens AA 6 , fol. $125 \mathrm{v}$.

16 Potter, War and Government, 102. At Troyes, the governors of Champagne resided in the royal palace (the former residence of the counts of Champagne) during the sixteenth century, while Dijon's échevins prepared rooms in the 'king's house' for governors' entries: Babeau, Rois de France à Troyes, 68; Dauphant, Royaume, 352; Gouvenain, Inventaire sommaire, Dijon, iii. 15. For governors lodging at royal residences, see also: F. Uzureau, 'Les Gouverneurs de l'Anjou et du Saumurois', Mémoires de la Société nationale d'agriculture, sciences et arts d'Angers, fifth series, 19 (1916), 27; Foulquet Sobolis, Histoire en forme de journal de ce qui s'est passé en Provence depuis l'an 1562 jusqu'à l'an 1607, ed. F. Chavernac (Paris, 1894), 7; Maurice Veyrat, 'Les gouverneurs de Normandie du XV e siècle à la Révolution', Études normandes (1953), 564.

17 AM Nantes AA 38.

18 R. C. Famiglietti, Royal Intrigue: Crisis at the Court of Charles VI, 1392-1420 (New York, 1986), 148. 
of this royal honour to governors' entries. When Charles de Bourbon entered Abbeville in 1520 as governor of Picardy, the town council offered the duke its keys 'considering that he is a prince of the blood and lieutenant-général of the king. ${ }^{19}$ While the échevins noted his status as a prince of the blood, it was his position as lieutenant-général that entitled him to receive the town's keys. Whereas nobles who insisted on the right to a key presentation at their entries as a means to boost their status were refused this honour, the granting of keys to provincial governors took place without debate because they represented the person of the monarch. Indeed, urban governments only gave their keys to the people the king had named governor. When Claude de Savoie, governor of Provence, made the Corsican mercenary captain Sampieru Corsu governor in his place on 3 October 1560, the consuls of Aix-en-Provence refused to offer Corsu their keys. ${ }^{20}$ As he was not appointed directly by Francis II, Aix's consuls did not feel obliged to hand over their keys to Corsu because he did not represent the king.

The submission of keys to governors was connected to oath taking and municipal councils required governors to confirm urban liberties at their inaugural entries. In advance of Claude de Savoie's inaugural entry into Aixen-Provence in 1547, the town council compiled a list of its privileges which the governor then swore to uphold at his entry. ${ }^{21}$ At the other end of the kingdom, in Picardy, Amiens did the same for Antoine de Bourbon's entry in $1541 .{ }^{22}$ It was important for urban administrations to have governors take an oath to maintain their rights as the extent of the governor's authority was a potential threat to municipal liberties. On 12 February 1550, the civic leaders of Nevers had Francis of Cleves, governor of the Nivernais, take two oaths, by which he swore to respect the privileges of the city and its suburbs. ${ }^{23}$ Certainly, some governors attempted to use their powers to infringe on local liberties (such as John of Berry, governor of Languedoc, in the late fourteenth century). ${ }^{24}$ In order to avoid such complications, town councils used a governor's entry to guarantee their privileges. Agen's consuls required the governors of Guyenne

19 Ledieu, Inventaire sommaire, Abbeville, 152; Potter, War and Government, 98.

20 AM Aix-en-Provence в B 46, fol. 47r. For Corso, see: Antoine-Marie Graziani and Michel Vergé-Franceschi, Sampiero Corso (1498-1567): un mercenaire européen au XVIe siècle (Ajaccio, 1999).

21 AM Aix-en-Provence B B 44, fols. 3or, 34r, в B 45, fol. 17r.

22 AM Amiens вв 23, fol. 87r.

23 Parmentier, Archives de Nevers, i. 145.

24 André Castaldo, Seigneurs, villes et pouvoir royal en Languedoc: le consulat medieval d'Agde (XIII $-X I V^{e}$ siècles) (Paris, 1974), 416-17. 
to swear not to derogate or infringe upon municipal privileges at their inaugural entries. The text of this oath was then written down, signed by the governor and deposited in the town's archives, so that the consuls could produce it should the governor threaten their rights in the future. ${ }^{25}$ In Dauphiné, where the governor possessed extensive powers (including the right to issue acts of the parlement in his own name), it was particularly important for municipal councils to obtain a guarantee that he would respect their privileges before admitting him behind their walls. ${ }^{26}$ In December 1497, Grenoble, the capital of Dauphiné, used relics to sacralise the oath taking for the entry of the governor, Jean de Foix. The consuls ensured that the oath taking took place in front of the cross of Notre Dame, which Jean kissed before swearing to uphold the city's liberties. ${ }^{27}$ For the entry of Charles de Bourbon as governor-legate of Avignon in 1473, the consuls constructed a temporary wooden chapel outside the Saint-Lazare gate, which they filled with powerful relics including those of the local saint, Agricol. ${ }^{28}$ Before being admitted into Avignon, the consuls asked Charles to take an oath to uphold the city's liberties in a service held in the temporary church..$^{29}$ As Pope Sixtus IV had appointed Charles to the position of governor-legate at Louis XI's instigation, the measures Avignon's consuls took to sacralise Bourbon's oath reflected their concern to safeguard their rights in response to the growth of French power in the city. ${ }^{30}$

Although the bulk of the oaths governors took at their entries required them to respect the rights that the king had already granted the town, the monarch could appoint a governor to make an entry and confirm urban liberties in his name. Following the incorporation of Provence into the kingdom of France in 1481, Palamède de Forbin, the incumbent governor of Provence, made a series

25 Auguste, Inventaire sommaire, Agen, 15, 22.

26 Lemonde, Temps de Libertés, 78-80.

27 Ам Grenoble вв 2, fols. 50v-51r. See also: A. Lemonde, 'Les entrées solennelles en Dauphiné', in Gilles Bertrand and Ilaria Taddei, eds., Le destin des rituels: faire corps dans l'espace urbain, Italie-France-Allemagne (Rome, 2008), 149. At Auch, the municipal council created a special volume of extracts from the gospels of Matthew, Mark, Luke and John, specifically to be used when requiring governors to respect municipal liberties: AC Auch AA 1, fol. 31v.

28 Aм Avignon в B 4, fol. 37v.

29 AM Avignon BB 4, fol. 37v; P. Pansier, 'L'entrée à Avignon du gouverneur légat Charles de Bourbon, le 23 novembre 1473', Annales d'Avignon et du Comtat Venaissin (1913), 211-12. For this entry, see also: Rouchon, 'Rituels publics', 39-59.

30 There was controversy surrounding this appointment and Sixtus IV replaced Charles de Bourbon in 1476 with his nephew Giuliano delle Rovere (later Pope Julius II): M. R. Rey, Louis XI et les états pontificaux de France au XVe siècle (Grenoble, 1899), 143-9o. 
of entries into Provençal towns and cities, confirming their liberties on behalf of Louis XI. ${ }^{31}$ Hoping to exploit the French king's unfamiliarity with their rights, the citizens of Marseille inserted additional liberties into the corpus they asked Forbin to confirm on Louis xI's behalf. ${ }^{32}$ Furthermore, Agen's consuls took an oath of loyalty to Louis XI through the hands of the governor of Guyenne, Jean de Lescun. ${ }^{33}$ As Agen had been under French rule for less than a decade by the time of Louis's ascension in 1461, the king took the unusual step of sending his governor to the town to safeguard his rule by obtaining the oath of loyalty he would typically receive at his inaugural entry. This was part of a wider move by Louis to secure his hold over the former Lancastrian territories in France, probably because he was suspicious of the loyalty of his subjects from these regions. Within days of his father's death, Louis XI sent his councillor, Jehan Desteur, lord of La Barde and maitre-de-hotel, to take possession of Rouen (including the city's castle, palace and bridge) and place twelve of the most powerful townspeople in custody. Louis also instructed Desteur to have the Rouennais take the oath of loyalty they would customarily give at a king's inaugural entry. ${ }^{34}$ Furthermore, on 28 August, Louis XI sent Louis d'Estouteville, recently appointed governor of Normandy, to take formal possession of Rouen for the Crown and receive the city's keys..$^{35}$ Monarchs attributed a high value to such ceremonies in the fifteenth century and the Lancastrian monarchy used the same tactics to secure the loyalty of its French subjects. ${ }^{36}$

31 AM Aix-en-Provence AA 4, fol. 17r, AA 8, fol. 5r, AA 16, fol. 47v; AM Arles BB 5, fols. 271r-73r; Dupont-Ferrier, Gallia regia, v. 7-8. The liberties of Milan (which was conquered by Francis I in 1515) were confirmed by the governor of the Milanais, Charles, duke of Bourbon, during Francis I's visit to Grenoble in 1516: Pierre de Vassière, ed., Journal de Jean Barrillon, sécretaire du chancelier Duprat 1515-21, 2 vols (Paris, 1897-99), i. 219.

Mireille Zarb, Histoire d'une autonomie communale. Les privilèges de la ville de Marseille du $X^{e}$ siècle à la Révolution (Paris, 1961), 115.

33 Auguste, Inventaire sommaire, Agen, 22. Louis XI appointed Jean the governor of Guyenne and marshal of France in August 1461: Vaesen and Charavay, Lettres de Louis XI, ii. 34; Dupont-Ferrier, Gallia regia, iii. 424.

34 Desteur arrived in the city on 29 July. Rouen's échevins tried to pre-empt the king's actions. On 24 July (two days after they learnt of the death of Charles VII), they sent a delegation to Brabant to take an oath of loyalty to Louis on behalf of the city: AD Seine-Maritime, AM Rouen A 8, fols. 19ov, 195r.

35 AD Seine-Maritime, Am Rouen A 8, fol. 142r.

36 Murphy, 'Ceremony and Conflict', 112-13; idem, 'War, Government and Commerce: The Towns of Lancastrian France under Henry V's Rule, 1417-22', in Gwilym Dodd, ed., Henry V: New Interpretations (Woodbridge, 2013), 253, 255-56. 
While the move by urban governments to have their liberties confirmed at court at the beginning of a monarch's reign led to the gradual removal of the oath taking from royal entries, some towns reintroduced this element into governors' entries during times of political instability as a means of safeguarding their rights. In the speech that Dijon's mayor delivered to Charles of Lorraine, duke of Mayenne and governor of Burgundy, outside the gate of the abbey of Champmol on 24 July 1574, he asked the duke to confirm the city's liberties in the name of the king. ${ }^{37}$ With the death of Charles IX on 30 May 1574, the Crown passed to his brother Henry, duke of Anjou and king of Poland. As Henry had not returned to France from Poland by the time of the duke of Mayenne's entry into Dijon, the échevins had been unable to have their rights confirmed. There was an uncertainty about the status of municipal privileges during the transference of power between rulers. As municipal councils considered governors to wield royal authority on the king's behalf, Dijon used Mayenne's inaugural entry to secure its rights. ${ }^{38}$ The échevins' request to have Mayenne confirm their liberties on the king's behalf also represents an effort by Dijon's municipal council to restore the traditional swearing of urban liberties (which Charles Ix had removed in 1564) to the foreground of a ceremonial entry. In addition, governors were also important for the confirmation of urban liberties at court. When Rouen's échevins learnt of Francis I's ascension to the throne in January 1515 , they immediately sent a delegation to Paris to obtain the confirmation of their privileges. It was Charles d'Alençon, the new governor of Normandy, who introduced the municipal delegation into Francis's lodgings, where they were able to gain an audience with the king and obtain his confirmation of the city's liberties. ${ }^{39}$ As these examples illustrate, provincial governors came to play a key role in the renewal of urban liberties by the sixteenth century. Accordingly, town councils deployed a range of strategies at governors' entries which were intended to win the lasting friendship of these powerful officials. The offering of the canopy was foremost amongst these tactics.

37 Entrées et réjouissances dans la ville de Dijon (Dijon, 1885), 18-19. For Mayenne's subsequent relationship with Dijon, see: Henri Drouot, Mayenne et la Bourgogne: étude sur la Ligue (1587-1596), 2 vols (Paris, 1937).

38 Henry III did not return to France until early September 1574: J.-F. Solnon, Henri III: un désir de majesté (Paris, 2001), 187. 


\section{The Canopy}

While there was a straightforward incorporation of some marks of sovereignty into governors' entries (such as the key presentation, oath taking and the confirmation of guild masters), the use of the canopy was a contested honour and debates about it dominated discussions of governors' entries across the kingdom. Although French towns were accustomed to present their keys to the king's representatives, the canopy was strongly associated with the monarch's person. As a symbol of sovereignty, it appeared above the king on representations of royal power, including seals and coins. ${ }^{40}$ It was an honour that not even the most exalted late medieval French princes claimed as their right. For example, Philip the Good (one of the most powerful rulers in fifteenthcentury Europe) refused the canopy offered to him at his entry into Besançon in $1442 .{ }^{41}$ However, the ascendancy of the provincial governors in the late fifteenth century gave a fresh impetus to debates on the canopy, particularly as urban governments had to decide if a governor's status as the king's deputy entitled him to this honour at his entries.

Some of the earliest discussions about the use of the canopy occurred in Rouen's council chambers. The French monarchy considered Normandy to be one of the kingdom's most important regions and this was reflected in the high status of its governors (three governors of Normandy went on to become kings of France). ${ }^{42}$ When Rouen's échevins learned that Louis, duke of Orléans (who later ascended to the throne as Louis XII), was to enter the city as governor of Normandy in 1492, they held a debate about whether or not to raise a canopy

40 Guenée and Lehoux, Entrées royales françaises, 14-15.

41 Henri Beaune and J. D’Arbaumont, ed., Mémoires d'Olivier de La Marche, 4 vols (Paris, 1883-88), i. 278. Dijon raised a canopy above Charles the Bold at his entry in 1474, though this can be explained by the political context of the entry. Charles was returning from Trier, where he had expected Emperor Frederick III to invest him with the Crown of a restored kingdom of Burgundy. While Charles failed to realise this ambition at his meeting with the emperor, it is likely that Dijon's échevins prepared the entry in expectation of receiving a crowned monarch: Hurlbut, 'Inaugural Entries', 112.

Louis XII, Francis I and Henry II. In addition, the dauphin, Francis, was made governor of Normandy in 1531, though he died before he could come to the throne: Veyrat, 'Gouverneurs de normandie', 569-71, 574-75. The dauphin was frequently the titular governor of Normandy and the actual administration of the province was given to lieutenants to rule in his absence, such as Admiral Chabot who was appointed to govern Normandy in the place of Dauphin Francis on 21 August 1531: Labande, Correspondance de Joachim de Matignon, xxx; Catalogue des actes de François I ${ }^{\text {er }}$, vi. 266. 
above him. After protracted discussions, the échevins decided not to offer Louis a canopy, declaring that the position of governor did not warrant it. ${ }^{43}$ Rouen's debates about the use of the canopy intensified in 1515 when the échevins spent five months discussing the reasons for and against honouring the new governor of Normandy, Charles, duke of Alençon, with a canopy. Royal officials based in Rouen, including the grand sénéschal, Louis de Brézé, advised the municipal council not to grant the canopy to the duke as it was a right pertaining to the king alone. In addition, Nicole Caradas, the king's advocate in the bailliage, advised Rouen's leaders to welcome the duke with all honours except the canopy, reminding the échevins that they had not given Louis of Orléans one in 1492. Nonetheless, Rouen's échevins discounted the advice of the royal officials and decided to prepare a canopy for Louis but with the caveat that it was to be a less honourable one than that given to the king. ${ }^{44}$ In short, Rouen's initial decision to grant the governor a canopy was made by the municipal council rather than being imposed by the Crown; indeed, the judgement was taken against the advice of the monarch's agents.

Although the ruling issued by Rouen's échevins in 1515 may have been influenced by the fact that in 1492 they had denied granting a canopy to a governor who later ascended to the throne, the principal reason why the city council offered a canopy to Alençon was because it allowed them to reward the duke for his services to the city. According to the municipal deliberations, the échevins accorded the duke this honour in return for the actions he had taken on their behalf at court regarding the exemption from the franc-fief, which was a tax non-nobles had to pay when purchasing noble lands. As we saw in chapter two, this was a crucial issue for the wealthy townspeople who wanted to move into landholding. The duke of Alençon's success in obtaining this tax exemption benefitted Rouen's elite, who saved money and gained honour by holding lands in the same manner as the nobility. ${ }^{45}$ Furthermore, as the duke's brother-in-law had recently ascended to the throne as Francis I, Rouen's ruling elite expected him to be in a strong position to promote their affairs at court. In the same month that Francis I came to the throne (January 1515), Alençon told Rouen's municipal council 'Messieurs, if you have any business with the king, I will make the request and seek after it and be your means towards him.' ${ }^{46}$ There was also a chance that Alençon could become the next king of France

43 AD Seine-Maritime, AM Rouen A 9, fol. 54r.
44 AD Seine-Maritime, AM Rouen A 11, fol. 3r.
45 Chevalier, Bonnes villes, 102.
46 
as he was first in line to the throne after Francis (in fact, he was called the dauphin before the birth of Francis I's first son in 1523$).{ }^{47}$ As part of the speech Rouen delivered to Alençon immediately before raising the canopy above him, the échevins asked the governor to uphold the town's privileges and expressed their hope that he would render effective justice, particularly through the punishment of fraudsters. ${ }^{48}$ In other words, as well as granting a canopy to reward Alençon for his past successes, the municipal council also emphasised his future responsibilities as governor by highlighting the measures they expected him to take on their account. Rouen's decision to grant the governor a canopy was taken out of self-interest and as a means to reward a proven broker for his efforts on the city's behalf. By granting Alençon the uncustomary honour of the canopy (which, even as the king's brother-in-law, he could not claim by right), the municipal council consolidated its relationship with the incumbent governor by supporting the public presentation of his power.

An entry ceremony provided municipal councils with an opportunity to deploy various markers of esteem (such as gestures, special dress and objects), which they used to articulate the governor's authority and social standing. ${ }^{49}$ As provincial governors rose to prominence in the sixteenth-century, efforts to display their honour in public became increasingly apparent. From the early sixteenth century, governors regularly attended public functions (including entries) accompanied by large entourages composed of high-status figures. ${ }^{50}$ When Louis de Brézé made his inaugural entry as governor of Normandy into Rouen on 27 September 1526, his entourage included the bishops of Lisieux, Évreux, Angôuleme and the abbot of Bernay, the baillis of Évreux and the Cotentin, as well as numerous other lords. ${ }^{51}$ Likewise, when François de Montmorency entered Paris in 1538 as the governor of the Île-de-France, he was accompanied by thirty-six noblemen from his household, while Antoine de Bourbon, the governor of Guyenne, entered Limoges in 1556 with a large entourage composed of a number of regional dignitaries, including

47 Vassière, Journal de Jean Barrillon, i. 9.

48 Veyrat, 'Gouverneurs de normandie', 562.

49 For the display of status, see: E. Dravasa, Vivre noblement. Recherches sur la dérogeance de noblesse du XIV e aux XVI e siècles (Bordeaux, 1965); A. Jouanna, 'Recherches sur la notion d'honneur au XVI ${ }^{\mathrm{è}}$ siècle', Revue d'histoire modern et contemporaine 15 (1968), 611-13; Howard Kaminsky, 'Estate, Nobility, and the Exhibition of Estate in the Later Middle Ages', Speculum 63 (1993), 679-81.

$50 \quad$ Harding, Power Elite, 21.

$5^{1}$ AD Seine-Maritime, AM Rouen A 12, fol. 71r; Veyrat, 'Gouverneurs de normandie', 562. 
the bishops of Mende and Oloron, as well as the lords of Cars, Lavauguyon, Pompadour and Roanne. ${ }^{52}$

Governors could also increase their public position by refusing the honours offered to them at their entries. For example, Philippe Chabot, the governor of Burgundy, declined the canopy presented to him at Dijon in 1526.53 By refusing this honour, governors could attempt to increase their standing with the king. In particular, governors exploited uncertainties surrounding the use of the canopy to win praise for their deference. Anne de Montmorency, governor of Languedoc, turned down the canopy at his entry into Toulouse on 27 July 1533. As he was entering the city shortly in advance of the dauphin and the king, Montmorency could use his refusal of a customary mark of sovereignty to win favour with both the current king and the expected future monarch. ${ }^{54}$ Montmorency also refused the canopy when it was offered to him at Béziers the following month, again just before the king was due to enter the town. ${ }^{55}$ By publicly declining a canopy in deference to the king, governors could win more honour and acclaim than accepting it because it allowed them to appear humble before the monarch. ${ }^{56}$ Whether or not the governor accepted the canopy, the key point was that municipal councils offered him the prospect of winning honour in one form or another. In some parts of the kingdom, the refusal of the canopy became a traditional element of a governor's entry. In fact, it was customary for the governors of Guyenne to refuse the canopy and then enter with it carried behind him. ${ }^{57}$ In this way, the governor could appear respectful of royal authority and still have the honour of entering with it (if not under it), thus illustrating that he represented royal authority in the king's absence.

While the initiative to grant a canopy to governors lay with municipal councils, once the precedent was set it was difficult to reverse. The inclusion of a canopy quickly became a routine element of a governor's entry, rather than an

52 Tuetey, Registres Paris, 1527-1539, 396; Potter, War and Government, 102-3; Reuben, Registres consulaires, Limoges, ii. 110.

53 BNF Collection de Bourgogne 45, fol. 28v; Gouvenain, Inventaire sommaire, Dijon, iii. 15.

54 AM Toulouse AA 5/94.

55 Domarion, Entrée de François I ${ }^{\text {er }}$, Béziers, 39.

$5^{6}$ Emperor Charles v initially declined the canopy offered to him at his entry into Paris in 1540, stating that it was an honour that belonged to the French king, though after this show of due defence he relented and entered under it: Guérin, Registres Paris, 1539-1552, 9.

57 Godefroy, Cérémonial françois, i. 1023-4. In the seventeenth century, Louis XIV preferred to have the canopy carried in front of him rather than above him. Lawrence Bryant suggests that this was because 'his glory would be hidden underneath it': Bryant, King and the City, 104 . 
additional honour urban governments used to reward their brokers. To illustrate, when Louis de Brézé entered Rouen as governor of Normandy in 1526, he was accorded a canopy without the protracted debates that surrounded the entries of 1492 and 1515.58 By the 1520 s, Rouen had lost the initiative to grant this honour: it was now a standard practice to offer a canopy to governors at their entries. While Louis de Brézé had advised Rouen's échevins not to grant a canopy to Louis of Orléans in 1492 (because it was a right belonging to the king alone), he did not refuse this honour at his own inaugural entry into Rouen as governor of Normandy thirty years later.

Due to the regional nature of governorships, canopies were introduced into governors' entries across the kingdom at different times. It was first used at Dijon in 1500 for the entry of Engilbert de Cleves, whereas it was not used at Grenoble until the entry of Guillaume Gouffier, governor of the Dauphiné, in $15^{20 .} .^{59}$ The introduction of the canopy reflected local political circumstances. It was first used at Chalôns-en-Champagne in 1524 for the inaugural entry of Claude of Lorraine. As well granting Claude a canopy, Chalôns'échevins offered both him and his wife gifts of silverware. This gesture formed part of the municipal council's drive to bind itself to Claude, who was emerging as one of the most powerful people in France in 1520 s. Shortly after becoming governor of Champagne, Claude was appointed to the king's council; furthermore, he became one of the leading members of Louise of Savoy's regency government during Francis I's imprisonment in $1525-6$. Following his release from captivity, Francis raised Claude to the position of grand veneur. ${ }^{60}$ As one of the principal offices in the royal household, it provided Claude with extensive access to the king. ${ }^{61}$ By offering the canopy and other distinctions to the governor at his entry in 1524, Chalôns' échevins were able to develop a friendly relationship with one of the kingdom's most powerful brokers, which worked to the town's benefit throughout the 1520 and beyond.

While canopies were first introduced into governors' entries in response to local circumstances, the use of these objects developed into a national trend by the mid-sixteenth century. This was because provincial governors were in a competition for public prestige with their peers. When news began to circulate at court that some towns and cities were offering canopies to their governors, those based in other parts of the kingdom began to demand the same honours.

\footnotetext{
58 AD Seine-Maritime, AM Rouen A 12, fol. $18 \mathrm{v}$.

59 Harding, Power Elite, 12.

6o Stuart Carroll, Noble Power during the French Wars of Religion: The Guise Affinity and the Catholic Cause in Normandy (Cambridge, 1998), 15.

61 Carroll, Martyrs and Murderers, 29-31.
} 
As governors entered towns with high-status individuals in their entourages, many nobles were able to witness first-hand how their equals were received. While the towns of Picardy had no tradition of granting canopies to their governors, Louis, prince of Condé, insisted that Amiens' échevins carry one above him during his inaugural entry into the city in 1565 . Condé claimed that French governors were due the honour of a canopy and he cited the examples of Jacques d'Albon, governor of the Lyonnais, and Charles de Bourbon, governor of Dauphiné, who had been granted canopies at their entries. Condé had been present at Jaques d'Albon's inaugural entry into Lyon in 1550, where he saw firsthand the consuls carry a canopy above the governor as he progressed through the city. ${ }^{62}$ In addition to Condé, three other future governors were present at d'Albon's entry: Robert de La Marck (governor of Normandy from $155^{2}$ to 1556); Jacques de Savoie (governor of Lyonnais from 1562 to 1571) and Charles de Bourbon (governor of Dauphiné from 1563 to 1565), who Condé mentioned to Amiens's échevins as a further example of the honours he was due to receive as a governor. Nonetheless, Amiens' échevins refused Condé's demand, informing the prince that his own brother, Antoine de Bourbon, was not granted a canopy when he entered the city as governor of Picardy in $1541 .{ }^{63}$ Furthermore, they told Condé that royal orders prohibited the canopy from being granted to anyone but the king. ${ }^{64}$ Condé's claim to this honour prevailed over Amiens' protests and from his entry onwards the city council raised canopies above its governors. ${ }^{65}$ While Amiens had tried to retain the initiative to grant this honour by hiding behind the royal prerogative, the use of the canopy had become an established part of a governor's entry by the mid-sixteenth century. This was to the detriment of town councils, as they lost the ability to grant (or withhold) this honour and thus persuade governors to act on their behalf.

Furthermore, the granting of canopies to provincial governors encouraged other prominent figures in the kingdom to demand this honour, such as Charles, duke of Bourbon, constable of France, who informed Lyon's town council that he wanted a canopy carried above him at his entry into the city in 1515 . As the governor of Languedoc, Charles could expect a canopy when he entered the towns and cities in his province; however, as Lyon lay outside

62 Lucien Romier, Jacques d'Albon de Saint-André, maréchal de France (1512-1562) (Paris, 1909), 255; Ам Lyon в в 71, fol. 18or.

63 While Antoine was accorded marks of honour such as the key presentation, he was not granted a canopy: AM Amiens BB 23, fols. 87r-87v.

64 Ам Amiens в в 37, fols. 66r, 69r; Harding, Power Elite, 13.

65 For canopies at the entries of the following governors of Picardy, see: Ам Amiens в в 40, fol. 2 or (duke of Longueville, 1571), and в в 48, fol. 28r (duke of Nevers, 1587). 
his gouvernement, the duke could not claim this mark of esteem by virtue of his status as governor of Languedoc. Instead, Charles informed Lyon's consuls that he was due a canopy because his appointment as constable on 12 January 1515 made him the most important person in the kingdom after the monarch. ${ }^{66}$ Even so, Lyon refused to grant the duke a canopy in an effort to retain its control over this mark of distinction. As the consuls did not want to give an outright refusal to one of the kingdom's leading men, they drew on their network of influential friends at court to tactfully decline the constable's request. They enlisted Florimond Robertet (who was then the chief royal financial officer and one of the most powerful people in France) to write a pacifying letter to the duke reminding him that the right to a canopy was an honour reserved for the king. ${ }^{67}$

Whereas Lyon's consuls denied Charles de Bourbon's request for a canopy by claiming that it appertained to the monarch alone, Paris's échevins devised a strategy to justify giving a canopy to the chancellor of France, Antoine Duprat, when he entered the city on 18 December 1530 . Although the échevins initially refused the chancellor's request for this honour by claiming that it was a royal right, they soon changed their minds. As the chancellor of France, Duprat was in a good position to help the city council, and the councillors wanted to grant the chancellor the distinction of a canopy to try and curry favour with him. Nonetheless, as a commoner who had risen through the ranks of the royal administration, Duprat had no basis on which to claim this honour; in fact, the position of chancellor, while powerful, did not confer on the holder the right to make an entry, let alone the royal privilege of a canopy. As Duprat was widely loathed by the general population of Paris, the échevins searched for a precedent to justify their aim to offer him this mark of esteem. ${ }^{68}$ In particular, the city council needed to persuade the capital's guildsmen (who carried the canopy above the monarch during royal entries) of Duprat's right to this honour. Fortunately for the échevins, Duprat had been appointed papal legate earlier that year (4June 1530). This meant that the city council could claim that Duprat was entitled to a canopy because he was the pope's representative in France. As well as allowing Paris's rulers to flatter Duprat, the incorporation of this mark of distinction into his entry enabled the échevins to gain access to the chancellor. While representatives from the city's most powerful guilds traditionally carried the canopy along different sections of the processional route, the municipal council revised this custom for Duprat's entry. Instead, the échevins

\footnotetext{
66 BNF Collection de Bourgogne 45, fol. 25v; Dupont-Ferrier, Gallia regia, iii. 488.

67 Guigue, Entrée de François premier, Lyon, xxi.

68 For Parisians' antipathy towards Duprat see: Knecht, 'Francis I and Paris', 25.
} 
ruled that they would carry it along the first part of the route (from the gate of entry at Saint Jacques up to the church of Saint Benoit). They sent a municipal sergeant, Jacques Beguin, to tell the goldsmiths not turn up on the day of the entry as they were no longer required to carry the canopy. Paris's échevins once again used past precedent to justify their supplanting of the goldsmiths. After searching through the city council's archives for accounts of previous entries, they discovered that the échevins had carried the canopy along the first stage of the intramural procession for the entries of the cardinals of Amboise (1502) and Luxembourg (1517).69 While Georges, cardinal of Amboise, was also Louis XII's leading councillor, it was his status as papal legate which was important for the échevins. Although some French towns and cities accorded ceremonial entries to leading royal councillors this was not a sufficient enough precedent to allow the granting of a canopy to Duprat. Hence, Paris emphasised Georges d'Amboise's status as legate rather than councillor. Furthermore, the city council enlisted Pierre Clutin (the prévôt des marchands at the time of Philippe of Luxembourg's entry) to assure the townspeople that the échevins had carried the canopy at the cardinal of Amboise's entry. ${ }^{70}$

It was desirable for Paris's échevins to be the first group to carry the canopy above Duprat, as it allowed them to underline their role in organising the entry and according him this uncustomary honour (in return for which they sought his favour). As the chancellor of France, Duprat was one of the most important people in the royal administration. Because he was largely resident in Paris, Duprat was in a good position to listen to the city council's pleas for tax reduction. The level of taxation the Crown placed on Paris grew increasingly heavy during the 1520 and Francis I's levying of a tax of 100,000 écus on the capital in 1528 brought the city close to breaking point. The échevins struggled to collect this unpopular tax from the financially exhausted population and they had to send the civic militia to the houses of those who refused to contribute. The unrest continued into 1529, when further financial difficulties were placed on the population as a result of the so-called 'Ladies' Peace' of August 1529 which set the ransom of the king's sons (who were then in captivity in Madrid) at two

69 Bonnardot, Registres Paris, 1499-1526, 67, 237.

$70 \quad$ Tuetey, Registres Paris, 1527-1539, 92. Other towns and cities employed this tactic during this period of heavy taxation: Duprat also had a canopy raised above him at his entries into Dijon (1530), Rouen (1532) and Toulouse (1533): BNF Collection de Bourgogne 45, fol. 29v; AD Seine-Maritime, AM Rouen A 13, fol. 18r; AM Toulouse AA 5/96. For legates' entries, see: Marc Smith, 'Ordre et desordre dans quelques entrées de légats à la fin du XVI ${ }^{\mathrm{e}}$ siècle', in Desplat and Mironneau, Entrées: gloire et déclin, 65-91. 
million écus. ${ }^{71}$ The bulk of the ransom fell on the principal towns and cities of the kingdom, which struggled to survive under this fiscal pressure. Paris's problems were exacerbated by the actions of the Crown, which took harsh measures against urban governments to compel them to raise this sum. ${ }^{72}$ Duprat's entry thus offered Paris's échevins an opportunity to win the favour of a central figure in the kingdom's financial administration who had the power to obtain a tax reduction for the city. ${ }^{73}$ Overall, the use of the canopy provided a powerful tool for urban administrations to deploy when seeking to develop networks of clientage at court.

\section{Governors' Networks of Clientage}

Governors' entries played a crucial role in the formation and consolidation of networks of clientage, especially as the king often appointed individuals with strong local connections to provincial governorships. For example, Louis II de la Trémouille was made governor of Burgundy in 1506 partly because of his ties to the region. ${ }^{74}$ The commissioning of governors from powerful local families whose wealth base already lay in the gouvernement (such as the Bourbons in Picardy or the Guise in Champagne) meant that they were less likely to be absentee rulers. ${ }^{75}$ This policy also gave a fresh boost to the formation of networks of clientage as governors developed relationships with those urban elites who could help them enhance their status. Ceremonial entries formed a crucial element in this system, which Robert Harding notes was based on

$71 \quad$ R. J. Knecht, 'Francis I and Paris', History 66 (1981), 30.

72 Knecht, Renaissance France, 136-37, 150-51.

73 For Duprat's financial influence see: Albert Buisson, Le chancelier Antoine Duprat (Paris, 1935), 216-78; Christophe Vellet, 'Entre légistes et ministres: Antoine Duprat (1463-1535)', in Michon, Conseillers de François I ${ }^{e r}$, 214-218.

74 Patrick Arabeyre and Catherine Chédeau, 'Les entrées des gouverneurs à Dijon au $\mathrm{XVI}^{\mathrm{e}}$ siècle', in D. Le Page, J. Loiseau and A. Rauwel, eds., Urbanités. Vivre, suivre, se divertir dans les villes ( $X V^{e}-X X^{e}$ siècles). Études en l'honneur de Christine Lamarre (Dijon, 2012), 198. For the rise of the La Trémouille family, see: William A. Weary, 'The House of La Trémouille, Fifteenth through Eighteenth Centuries: Change and Adaptation in a French Noble Family', Journal of Modern History 49 (1977), 1001-38.

75 Potter, War and Government, 66-67; Mark Konnert, 'Provincial Governors and their Regimes during the French Wars of Religion: The Duc de Guise and the City Council of Châlons-sur-Marne', Sixteenth Century Journal 25 (1994), 826-27. 
'reciprocation for past favours and in expectation of future ones. ${ }^{76}$ While a governor's term in office was usually short (five years or less) in the 1460 os and 1470s, the duration of their appointments increased considerably during the sixteenth century (indeed, all the governors of Burgundy in the second half of the sixteenth century remained in their post for more than two decades). Given the long tenure of their appointments, it was in the interests of municipal councils to use ceremonial entries to construct enduring friendships with their governors, who came from France's leading families (including the Bourbon, Guise and Montmorency). ${ }^{77}$ Louis XI appointed John, duke of Bourbon, governor of Languedoc because 'the said office requires a prince of the blood of great authority'. ${ }^{78}$ As governorships often remained in the same family, urban administrations attempted to use entries to build links with future governors. Honoré de Savoie, count of Tende, refused the entry ceremony (and gifts of silverware) Aix-en-Provence offered him in 1566 until his father, Claude de Savoie, the late governor of Dauphiné, had been buried. Yet the fact that Honoré declined these honours in advance of his appointment as his father's successor suggests that the consuls had altered him to their intentions in an effort to persuade him to enter the town. ${ }^{79}$ Aix's consuls probably wanted to use an entry to gain Tende's services as their agent; when his father made his inaugural entry into the town as governor in 1547 , it was with 'good heart that the town recognised what he [the governor] could do for it [Aix]'.80 Governors were especially attractive to urban administrations because they normally held other positions of power in addition to their role as governors. Louis de Brézé, governor of Normandy, was both chambellan and grand veneur to

76 Harding, Power Elite, 28. For governors and their networks of clientage, see also: Mark Greengrass, 'Noble Affinities in Early Modern France: The Case of Henri I de Montmorency, Constable of France', European History Quarterly 16 (1986), 275-311; Sharon Kettering, Patrons, Brokers, and Clients in Seventeenth-Century France (Oxford, 1986), 141-44; Konnert, 'Provincial Governors and their Regimes', 823-40; Malcolm Walsby, Counts of Laval, $43^{-79}$.

77 Davis Bitton, The French Nobility in Crisis, 1560-1640 (Stanford, 1969), 42-4S3; Carroll, Martyrs and Murderers, 223; Potter, Nation State, 120; J. M. H. Salmon, Society in Crisis: France in the Sixteenth Century (Tonbridge, 1975), 24-26; Zeller, 'Gouverneurs d'Auvergne', 163 .

78 Dupont-Ferrier, Gallia regia, iii. 484.

79 Ам Aix-en-Provence вв 63, fol. 7r. Likewise, on 14 March 1587 Bernard de Nogaret de La Valette made his inaugural entry as governor of Provence into Aix-en-Provence. He was the brother of the previous governor, Louis de Nogaret, duke d'Epernon (who entered Aix on 21 September 1586): Sobolis, Journal, 42.

8o Aм Aix-en-Provence в B 44, fol. 34r. 
Francis I, as well as being married to the court favourite Diane of Poitiers (later mistress to Henry II). ${ }^{81}$ Similarly, Jean de Bruges, governor of Picardy, was chambellan to Louis XII and a member of his royal council. ${ }^{82}$ In addition to sitting on the royal council, governors were frequently with the king at court or on campaign. Furthermore, having a governor for a broker could bring longterm rewards for towns because they were often appointed for life. Guillaume Gouffier, admiral of France, was governor of Dauphiné from 1519 until his death at the battle of Pavia in $1525 .{ }^{83}$ Likewise, Louis de La Trémouille was governor of Burgundy from 1506 until he, too, was killed at Pavia, while his predecessor, Engilbert of Cleves, also held this position for life. ${ }^{84}$

By the early sixteenth century, the combination of the governors' elevated social status and the long duration of their appointments allowed municipal councils to develop enduring networks of influence with individuals who had privileged access to the king. ${ }^{85}$ Their regular contact with the monarch - in addition to the crucial role they played in the running of the kingdom - led municipal councils to use entries to obtain governors' services as brokers. Lyon's consuls set aside a large sum of money for the entry of Jacques d'Albon, governor of Lyonnaise, in 1550 because he had 'great access and power' with the king, which they hoped he would use to obtain the city's exemption from the war subsidy (an issue that had preoccupied the consuls since Henry II's entry in August 1548). Furthermore, they hoped that d'Albon would encourage the king to repay the debts on the loans that the Crown had taken out at Lyon to fund its wars in Italy, which stood at the colossal sum of 6,86o,844 livres upon Henry II's ascension to the throne in $1547 .{ }^{86}$ Likewise, when Charles de Cossé-Brissac made his inaugural entry into Angers as governor of Anjou, the mayor used the extramural greeting speech to thank him for the efforts he had taken to obtain exemption from military quartering for the town. The mayor asked Charles to continue his endeavours on behalf of Angers, promising that

\footnotetext{
81 Dupont-Ferrier, Gallia regia, iv. 260.

82 Dupont-Ferrier, Gallia regia, iv. 460.

83 Pierre Carouge, 'Artus (1474-1519) et Guillaume (1482-1525) Gouffier', in Michon, Conseillers de François I ${ }^{e r}$, 239-42.

84 Dupont-Ferrier, Gallia regia, i. 420; ii. 319.

85 Rivaud, Villes et le roi, 201.

86 Ам Lyon вв 71, fol. 181r; Roger Doucet, 'Le Grand Parti de Lyon au XVIe siècle' Revue historique 171 (1933), 480. This sum rose to 11,700,00o livres by the time of Henry's death in 1559, which bankrupted the Grand Parti at Lyon: Salmon, Society in Crisis, 50; Ladurie, French Royal State, 44.
} 
the townspeople would honour him in return. ${ }^{87}$ Greeting speeches such as that given to Cossé-Brissac were not just designed to flatter: they had an instructional intent. When Charles of Mayenne, governor of Burgundy, made his first entry into Dijon in 1574, the mayor used his greeting speech to highlight the importance of 'clemency, justice and generosity. ${ }^{88}$ Urban elites used extramural greeting speeches to construct good relationships with governors that were based on reciprocal obligations. When Gaspard de Coligny, governor of the Île-de-France, entered Paris on 9 February 1551, soon after returning Boulogne to French rule, he was given a flattering speech by the prévot-desmarchands, Claude Guyot. In response to this greeting, Coligny stressed his capability to act as an intermediary between the king and the city. He told Guyot that he would act for the 'good and profit' of Paris, boasting that he knew people of 'great power, experience and sufficiency' who he could enlist to help the city in various ways. Paris cemented its relationship with Coligny by gifting him several of items of silverware (including two basins, two cups and two water jugs). The extent of the gifts pleased the governor greatly, thus making him more likely to use his networks of influence on the city's behalf. ${ }^{89}$

As with the monarch's entries, municipal councils used gift giving to bind governors to reciprocate. ${ }^{90}$ When Lyon's consuls offered Jacques d'Albon a gift of silverware following his entry in $155^{\circ}$ they also gave him petitions relating to their 'great and urgent business'. ${ }^{91}$ However, Lyon's urgency to bind d'Albon to act immediately on their behalf was not typical of the transactions

87 Uzureau, 'Gouverneurs de l'Anjou', 24. Similarly, when the duke of Bourbon entered Nevers as lieutenant-général on 9 July 1466 , they provided gifts to him 'in recognition of the good that he did in the past year for [the] town and region, during the divisions which were between the king and the lords, and also in honouring the good will and pleasure of the count of Nevers, who made it known that we had given him [a] good welcome': Parmentier, Archives de Nevers, i. 204-5.

88 Cited in Arabeyre and Chedeau, 'Gouverneurs à Dijon', 262.

89 Godefroy, Cérémonial françois, i. 1007.

9o Nonetheless, these efforts were not successful. Five months after entering Lyon, the consuls gifted d'Albon a silver chain in order to obtain a subsidy for the city. However, d'Albon stated that the gift did not bind him to this charge, claiming that the chain was 'in recompense for pleasures and services' that he had already done for the city: AM Lyon вв 72, fol. 194r. However, d'Albon did go on to advance the affairs of the city at court. See, for example, the letters he sent to Claude of Lorraine, the first minister of Henri II, and Anne de Montmorency, constable of France, on 28 July promoting the affairs of the city: AA 28, n. 57; Lucien Romier, 'Les deputes des villes en cour au XVI siecle', 1 Bulletin historique et philologique du Comité des travaux historiques et scientifiques (1909), 511. 
between urban elites and governors at entries. Relationships of clientage between governors and municipal elites were not normally based on an immediate transaction between the client and patron. Unlike the entry of the king who immediately granted new liberties in return for gifts - the provision of an entry (and gift) to a governor created an association that was based on delayed reciprocity, whereby the governor was typically rewarded either for past successes or in the expectation of future assistance. ${ }^{92}$ In return for promoting municipal interests at court, governors asked regional Estates for money and the governors of Languedoc were particularly adept at this tactic. Charles de Bourbon sent a letter to the Estates of Languedoc outlining the services he could provide for the province at court in return for which he requested the Estates to provide him with money. The promise of favours from one of the most powerful people in the kingdom was an attractive offer for the Estates of Languedoc, which voted to give him the substantial sum of 15,000 livres. ${ }^{93}$ Monetary gifts were often tied to specific requests. Following his ceremonial entry into Montpellier on 24 May 1426, the city government paid Jean, count of Foix, governor of Languedoc, the sum of 68,ooo francs on the condition that he used this money to bring an end to the destructive actions of mercenaries in the region. ${ }^{94}$ Likewise, In 1529 the Estates of Languedoc agreed to pay 6,00o livres to the new governor of the Languedoc, Anne de Montmorency (who was appointed to the position after the treason of Charles of Bourbon), if he could obtain a reduction in the number of troops billeted in the province (these soldiers had been particularly unruly). ${ }^{95}$ Similarly, in 1492 the Estates of Normandy voted to give 14,00o livres to Louis of Orléans in return for his services on behalf the province. ${ }^{96}$ Urban administrations used ceremonial entries to provide their contributions to these monetary gifts. ${ }^{97}$ As governors acted in the interests of a province, towns sought to have the inhabitants of the wider region - not just the townspeople - contribute towards the governor's gift. When Auch's consuls learnt that the king of Navarre, governor of Guyenne, was to enter their town, they brought together representatives from the surrounding region to give their consent to the offering (and cost) of a gift. ${ }^{98} \mathrm{In}$ addition to the high monetary value of the gifts, the increasing magnificence

\footnotetext{
92 Harding, Power Elite, $36-7$.

93 Brink, 'Royal Power', 56.

94 Alicot, Petit Thalamus de Montpellier, 473.

95 Brink, 'Royal Power', 56.

96 Veyrat, 'Gouverneurs de normandie', 561.

97 Dauphant, Royaume, $35^{2}$.

98 AC Auch B B 5, fol. 488v (for entry see: fol. 489r).
} 
of governors' entries (which mirrored those of the king) drained municipal budgets. The expense of the governor of Dauphiné's entry in 1548 left Grenoble unable to provide a first-rate entry for Henry II when he entered the city one month later. As a consequence, the monarch refused to confirm the city's liberties. ${ }^{99}$ Grenoble's municipal council was not alone in preparing increasingly magnificent entries for governors. We find a considerable evolution in the form of governors' entries across the kingdom between the later fifteenth and mid-sixteenth century, as towns sought to use these honours to encourage governors to act on their behalf.

We can track the evolution in governors' entries by looking at changes to the receptions staged at Dijon for the governors of Burgundy. While the 1481 entry of the first governor of Burgundy, Georges de La Trémouille, was a relatively modest affair, the échevins introduced a canopy (which was expensive to make) for the entry of Engilbert of Cleves in 1500. Furthermore, Dijon also presented Engilbert with a gift of silverware. ${ }^{100}$ For Louis de La Trémouille's inaugural entry in 1508 , the town council spent over 160 livres on a silver cup to offer him as a gift, in addition to paying to decorate his lodgings in the king's palace with expensive tapestries. ${ }^{101}$ When Philippe de Chabot entered the city in 1526 , the municipal council included dramatic performances in the procession for the first time. There was also a marked expansion in the scale of the gifts offered at this entry: not only did the échevins give eight items of silverware to the duke (six cups and two water jugs), they also provided gifts of silverware to his wife and his mother (in the same way that they would do for the king's female relations). Like the king's officers, those of the governor had the right to keep the canopy after his entry. As Chabot refused a canopy at his entry, the town council had to pay compensation of 100 sous to his officers (in addition to the costs of fashioning the now redundant canopy). ${ }^{102}$ The municipal council staged a particularly elaborate entry for the duke of Guise in 1544. Not only did the échevins increase the number of dramatic performances and hire musicians from the neighbouring town of Auxonne to perform on the stages, they also appointed the well-regarded painters Jean Dorrain, Denis Aubber and Guillaume Thomas to fashion the sets. The town council also commissioned

99 Aм Grenoble вв 14, fols. 42r-43r; Gluck, 'Entrées provinciales de Henri II', 216; Prudhomme, Histoire de Grenoble, 337.

100 Gouvenain, Inventaire sommaire, Dijon, iii. 15. For example, Narbonne paid 52 livres 10 sous for the canopy for the governor of Languedoc (Henri de Montmorency) in October 1563: AM Narbonne B B 1, fol. 25or.

101 Gouvenain, Inventaire sommaire, Dijon, iii. 15.

102 Gouvenain, Inventaire sommaire, Dijon, iii. 15. 
these artists to decorate the triumphal arches (a feature normally restricted to royal entries) they had decided to include in a governor's entry for the first time. In addition, the échevins paid almost 630 livres for a cup to offer the duke (over four times the cost of the gift they offered Louis de La Trémouille in 1508), as well as a further 364 livres for two gilded water jugs they gave to the duchess. ${ }^{103}$ When Claude of Lorraine, duke of Aumale, entered the city in December 1550, as well as erecting triumphal arches, the city council gifted the governor a silver statue of Hercules costing 400 livres. The scale of the decorations, the iconography and the cost of Claude's entry mirrored the reception Henry II had received at Dijon (indeed, the city council employed the same artists). ${ }^{104}$ By the second half of the sixteenth century, French towns were transferring the exalted language traditionally reserved for the king's entry to those of the provincial governors. The mayor of Dijon called the duke of Mayenne the 'image of God and one of his ministers on Earth' at his entry in $1574 .{ }^{105}$ In short, we can see a steady rise in the splendour and cost of governors' entries as they came to resemble those of the king.

The development of governors' entries at Dijon was echoed in other towns and cities across France. When the first governor of Lyonnnais, Tanneguy du Chastel, entered Lyon in 1462, he received a modest reception and gift. However, dramatic performances were included in the inaugural entry of the second governor, Cesare Borgia, duke of Valentinois, in 1498, along with an increase in the scale of the gifts. ${ }^{106}$ There was a steady escalation in the magnificence of governors' entries into Lyon throughout the sixteenth century: when Jacques d'Albon made his entry on 24 August 1550, the gift alone cost 1,200 écus. ${ }^{107}$ This was a considerable expenditure for the city, especially when we remember its dire financial situation (by the time of d'Albon's entry, Lyon had debts of more than 200,000 livres due to the war taxes Henry II had levied on the city). ${ }^{108}$ The city's high expenditure on d'Albon's gift is especially striking when we recall that these financial difficulties had caused the consuls to offer only modest

103 Gouvenain, Inventaire sommaire, Dijon, iii. 16-17.

104 Gouvenain, Inventaire sommaire, Dijon, i. 66; Entrées et réjouissances, Dijon, 7-13, 17-24.

105 Cited in Harding, Power Elite, 13. For the entries of the governors of Burgundy in the seventeenth century, see: Michael P. Breen, 'Entrer dans la politique municipale: les enjeux des factions dans les entrées dijonnaises de Louis II de Bourbon (1648) et Bernard de Foix de la Valette (1656)', in Philippe Hamon and Catherine Laurent, eds., Le pouvoir municipal de la fin du Moyen Âge à 1789 (Rennes, 2012), 103-21.

106 A. Péricaud, 'Gouverneurs de Lyon', Revue du Lyonnaise 12 (1840), 363-4.

107 Ам Lyon вв 71, fols. 205r-205v, 211r-212r.

108 Péricaud, 'Gouverneurs de Lyon', 369-70; Lucien Romier, Jacques d'Albon de Saint-André, maréchal de France (1512-1562) (Paris, 1909), 260-61. 
gifts to Henry II and Catherine de Medici when they entered the city two years earlier. ${ }^{109}$ The scale of d'Albon's entry formed part of the consuls' attempts to restore Lyon's finances by maintaining the support of a successful broker who had a good record of obtaining concessions for the city.110 The entries of some governors were especially magnificent. When Antoine de Bourbon, king of Navarre and governor of Guyenne, made his inaugural entry into Limoges in December 1556, the consuls prepared the most lavish entry yet staged in the city, probably as a consequence of his royal status. ${ }^{111}$ When the municipal delegation came to offer Antoine its keys, the governor received them while seated on an elevated stage covered in red cloth. Furthermore, the city council constructed a loggia for Antoine outside the gate of entry, where he received the harangue and watched the procession of townspeople pass before him. The governor processed through extravagantly decorated streets where he saw a number of plays staged in his honour. In addition, the city also paid for a magnificent entry for his wife, Jeanne d'Albret. ${ }^{112}$ As with royal entries, by the mid-sixteenth century urban governments tailored their receptions to suit the governor's expectations. For instance, Antoine de Bourbon sent his official, the lord d'Escars, to meet with Limoges' consuls in advance of his entry and advise them about the type of welcome he wanted. Governors' agents encouraged urban governments to stage honourable receptions for their masters by emphasising the extent of the good that the governor could do for them. Thus, the deputies Jacques d'Albon sent to Lyon in June $155^{\circ}$ in advance of his inaugural entry told the consuls that the governor could be a good friend to the city and that it would be to their benefit to prepare an honourable welcome in order to 'capture the grace and benevolence of M. de Saint-André. ${ }^{113}$ Aware that their powers made them attractive to urban governments, governors used their capability to act in a town's favour to encourage municipal elites to provide them with especially magnificent entries as these events underpinned their elevated social position. By using intermediaries (rather than approach the townspeople themselves), governors were able to remain aloof from the bargaining process.

\footnotetext{
109 AM Lyon в в 67, fols. 107r, 211v; Cooper, Entry of Henry II into Lyon, 16.

110 For example, just in advance of his entry d'Albon obtained 50,00o livres from the Crown to be put towards the city's fortifications: AM Lyon 71, fol. 181r.

111 Dast Le Vacher de Boisville, Liste des gouverneurs lieutenants généraux et lieutenants du roi en Guienne (Auch, 1898), 8.

112 Registres consulaires, Limoges, ii. 108-131.

113 Aм Lyon в в 71, fols. 18or-81r.
} 
As well as attempting to control the form of their own entries, governors began to influence how municipal governments received the king. For instance, Claude, duke of Aumale, governor of Champagne, decided who was to present the keys at Charles IX's entry into Châlons-en-Champagne in $1564 .{ }^{114}$ Overall, governors' input into the design of these ceremonies benefitted municipal governments because they were close to the king and knew what would please him. In advance of Charles IX's entry into Nîmes in November 1564, Henri de Montmorency, governor of Languedoc, advised the consuls that their plan to decorate the streets yellow and white would displease the king 'because his colours are white, blue and crimson' ${ }^{115}$ Governors were quick to offer advice to municipal councils because the overall quality of the entry contributed to their standing with the king. In 1533, François de Bourbon, governor of Dauphiné, wrote to Valence's consuls directing them to ensure that they had the necessary provisions for Francis I's entry. ${ }^{116}$ The issue of victualing was of particular concern to Montmorency because large numbers of people were travelling with the monarch on this progress (Francis was accompanied by the queen, the dauphin and their households). Furthermore, the increasingly military character of royal entries during the sixteenth century (when hundreds of armed guildsmen filed out of the town in procession to greet the king) was of particular concern to governors, who were responsible for ensuring the defence of their provinces. For Charles IX's entry into Narbonne, the governor, Henri de Montmorency, specified the type of weapons the participants in the extramural procession were to carry, with any infractions being subject to punishment. ${ }^{117}$ By having the city put on a good military display, the governor could show the king he was doing an effective job in the province. The military character of the parade was of special concern to Montmorency because Languedoc's Protestant population had recently taken up arms against the monarchy. By ensuring that the participants of the extramural procession were armed, Montmorency could use the entry to show the king he had the Catholic population of Narbonne ready to defend the town against any Protestant uprising.

Governors were valuable sources of information for urban governments when planning a royal entry. Because governors often accompanied the king on progress, they were able to provide municipal councils with information regarding the monarch's location. Between 29 November 1520 and 13 April 1521, the governor of Burgundy, Louis de La Trémouille, sent eleven

\footnotetext{
114 Pélicier, Inventaire sommaire, Châlons-sur-Marne, p. 7.

115 AM Nimes LL 10.

116 AM Valence BB 4, fol. 376r.

117 Ам Narbonne вв 2, fol. 6v.
} 
letters to Dijon's échevins about the king's location. ${ }^{118}$ It was crucial that towns received accurate information about the royal party's whereabouts so that they could prepare the gate of entry and decorate the processional route leading from it. ${ }^{119}$ Governors informed towns in their gouvernements about how the king had been received in other parts of the kingdom. This information was of great value to urban rulers who were in competition for the king's favour with other towns and cities across France. Governors also stimulated rivalry between the towns of their gouvernments by encouraging municipal councils to outdo their immediate neighbours as these entries reflected on his honour. Louis de Bruges, lieutenant-général of Picardy, informed Amiens' échevins about how Georges d'Amboise had been received at Noyon and Saint-Quentin in 1508.120 As well as being a papal legate and the archbishop of Rouen, Amboise was Louis XII's leading councillor and thus in a good position to assist Amiens with its petitions. Given Amboise's worth for the city, the échevins wanted to ensure that the entry they staged for him outdid those he received from their neighbours. As such, it was in the interests of both the town council and the governor (who could also expect to benefit from the entry) to provide important figures such as Georges d'Amboise with a good entry.

In return for staging magnificent entries, urban governments expected governors to use their powers to benefit townspeople. Mirroring royal entries, municipal councils devised a second greeting to take place at the governor's residence after the public entry, which they used to bring gifts and requests to him. The relationship between Antoine de Bourbon and Limoges' consuls was cemented during the harangue and gift giving which followed his public entry, when the governor 'replied to the said greeting, and offered to work for the protection and safeguard of the good of the town'.121 Similarly, in the days following Louis de Brézé's entry into Rouen in 1526 , the municipal council went to his rooms in the royal castle to make their greeting to the governor and offer him gifts of silverware. ${ }^{122}$ As well as requiring Brézé to uphold the city's rights and liberties, Rouen's échevins asked him to end to the depredations mercenaries

118 Garnier, Correspondance de Mairie de Dijon, i. 286-97.

119 When Charles of Navarre entered Tournai in 1353, he approached the city by the road leading to the Coquerel gate, when in fact the town had prepared the Bourdel gate for his arrival. As a result, two civic deputies had to lead Charles around the walls to the correct gate so that he could make his entry: La Grange, 'Entrées des souverains', 22.

120 Aм Amiens в в 21, fols. 2or-21r, 23r.

121 Reuben, Registres consulaires, Limoges, ii. 109-10, 127.

122 AD Seine-Maritime, Am Rouen A 12, fol. 38v. 
were causing to the region's population. ${ }^{123}$ The resurgence of the Anglo-French war in 1522 - particulalry the duke of Suffolk's invasion of northern France in 1523 - had left the north in fear of foreign attack, with Normandy becoming a militarised zone by the mid-1520s. ${ }^{124}$ Despite a fear of attack from England, Rouen resented the billeting of troops in the region because they harassed the local population and disrupted trade. Given Brézé's authority over the defence of Normandy, Rouen's échevins used his inaugural entry to petition him to ameliorate the situation on their behalf. When Périgueux's consuls offered Henry of Navarre, governor of Guyenne, a gift following his ceremonial entry on 10 January 1530, they told him that a combination of famine, the longstanding presence of soldiers in the region and 'other pernicious matters' had severely affected the town. ${ }^{125}$ As the municipal record of the entry shows, the councillors gave these gifts to Henry in the expectation that he would take action to improve the town's situation. ${ }^{126}$ Despite the fact that Henry held little influence with Francis I, his role as governor of Gueynne gave him the authority to improve the town's position. Possibly aware of Navarre's limited influence with the king, Perigueux's consuls asked him to assist them in ways that did not necessitate him having to approach the king. ${ }^{127}$ In order to encourage the success of their requests, some urban administrations notified the governor of the problems they were facing in advance of his entry. Before Claude of Lorraine made his inaugural entry into Dijon as governor in 1544, the municipal council sent a delegation to follow his progress through Burgundy in order to 'do him reverence' and inform him of their needs. ${ }^{128}$ The opportunity to speak directly to the governor about pressing urban needs was of great importance to urban administrations. Although kings' visits to provincial towns tended to be short, governors spent long periods in the urban settlements of their regions. This meant that civic elites could expect the provision of a good welcome to lead

\footnotetext{
123 AD Seine-Maritime, Am Rouen A12, fol. 4or.

124 Steven Gunn, 'The Duke of Suffolk's March on Paris in 1523', English Historical Review 101 (1986), 28-51; idem, 'The French Wars of Henry VIII', in Jeremy Black, ed., The Origins of War in Early Modern Europe (Edinburgh, 1987), 28-51; David Potter, 'Foreign Policy', in D. MacCulloch, ed., The Reign of Henry VIII: Politics, Policy and Piety (London, 1995), 101-33; Glenn Richardson, The Field of the Cloth of Gold (New Haven and London, 2013), $190-91$.

125 Henri Montégut, Dix entrées solennelles à Perigueux, 1470-1566 (Bordeaux, 1882), 38.

126 Montégut, Entrées solennelles à Perigueux, 38-39.

127 For Henry of Navarre's limited influence with Francis I, see: Jonathan A. Reid, 'Henri d'Albret, roi de Navarre (1502-1555)', in Michon, Conseiller de François I Ir, 440-41.

128 Gouvenain, Inventaire sommaire, Dijon, iii. 15.
} 
to the creation of a lucrative stream of influence at court by a powerful official who was in a good position to promote the town's business on a regular basis.

Although governors were the principal provincial agents of the central administration, they also postured as defenders of local privileges. ${ }^{129}$ In 1561 , Louis of Bourbon, duke of Montpensier and governor of Anjou, told Angers' échevins he would be their 'advocate and protector' at court. ${ }^{130}$ French towns used ceremonial entries to remind governors of their paternal role. When Francis of Cleves, governor of Nivernais, entered Nevers on 12 February 1550, the échevins called him 'our head and captain' and asked him to govern them with his 'accustomed natural goodness and clemency'.131 Similarly, when Béziers ceremonially welcomed Anne de Montmorency in 1533, the consuls called him 'our protector' during the extramural greeting and emphasised the paternal nature of his relationship with the town..$^{132}$ Moreover, during the banquet Béziers held for Montmorency on evening of his entry, the consuls notified him of the requests they intended to bring to the king (which related to the repair of their fortifications), who was due to enter the town in the following days. In order to reinforce their relationship with the governor and bind him to speak to the king on their behalf, the consuls offered Montmorency a silver plate. As soon as he received this gift, Montmorency thanked the consuls and assured them that he would speak to the king about the repairs that were necessary to ensure the town's security. ${ }^{133}$ As governors were mediators between urban elites and the Crown, municipal governments gave them magnificent entries in the expectation of receiving future assistance. In 1547, Aix-en-Provence gave Claude de Savoie, the governor of Provence, a particularly lavish entry in recognition of his capability to help the town. ${ }^{134}$ When Grenoble's consuls learned that Charles of Bourbon, governor of Dauphiné, intended to enter the city in May 1564, they decided to prepare a princely reception specifically so that they could offer him a request to extend their jurisdiction. ${ }^{135}$ Moreover, a governor's entry provided an important

129 Brink, 'Royal Power', 57; Chevalier, 'Gouveneurs', 303; Harding, Power Elite, 16.

130 Uzureau, 'Les gouverneurs de l'Anjou', 25.

131 Cited in Cosandey, Reine de France, 200.

132 Domarion, Entrée de François I ${ }^{e r}$, Béziers, 38-39. Similarly, the Estates of Languedoc also referred to Montmorency as the 'father and protector of the region'. Cited in Brink, 'Royal Power', 55. For Montmorency's role as a broker, see:Thierry Rentet, 'Anne de Montmorency

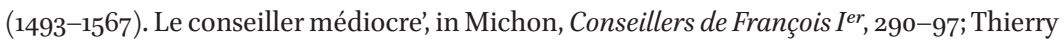
Rentet, Anne de Montmorency, grand maître de François I ${ }^{\text {er }}$ (Rennes, 2001), 305-19.

133 Domarion, Entrée de François I ${ }^{\text {er }}$, Béziers, 40.

134 Ам Aix-en-Provence вв 44, fol. 34r; Harding, Power Elite, 15.

135 Aм Grenoble вв 19, fol. 63r. 
opportunity for the smaller towns of his gouvernement to bring their matters to his attention. After the entry of Honorat de Savoie, marquis of Villars, admiral of France and governor in Guyenne, into Auch the town council sent a delegation to follow him to Agen with their complaints. ${ }^{136}$ Once a governor had made his inaugural entries into the towns of his gouvernement, he tended to settle in one of the region's principal cities. As a result, smaller towns could find it more difficult to gain contact with the governor. Accordingly, the entries a governor made at the beginning of his tenure supplied the governments of towns such as Auch with a favourable moment to promote their business with him.

Urban governments brought requests to governors at their entries because they held extensive local powers, particularly relating to the defence of their provinces. As such, municipal councils used entries to petition governors to reduce the military burdens placed on urban populations. ${ }^{137}$ When Louis, duke of Orléans, made his inaugural entry into Honfleur as governor of Normandy on 29 March 1492, Pont-Audemer sent a delegation to attend the entry and try to obtain a reduction in the number of soldiers the town was obliged to support. ${ }^{138}$ Furthermore, in provinces such as Burgundy and Normandy governors could determine appointments to positions in municipal governments, including that of mayor. ${ }^{139}$ Hence, urban elites sought to obtain governors' good favour at entries as a means to secure their hold over the highest positions in civic governments. In addition, governors possessed the necessary powers to defend municipal jurisdiction against encroachments from rival local authorities. In 1468, Louis de Laval, the governor of Champagne, supported Chalônsen-Champagne's échevins in their dispute with the clergy regarding the obligation to provide guet (which the clergy were normally exempt from). ${ }^{140}$ Governors enlarged the authority of urban elites in an effort to gain municipal backing for the Crown's efforts to curtail the power of the kingdom's princes. When Jean de Doyat, governor of Auvergne, entered Clérmont in July 1480, he took the side of the bourgeois in their dispute with the bishop over secular jurisdiction. In the name of the king, Doyat granted the townspeople the right to form a consulate and construct a town hall. ${ }^{141}$ At the time of Doyat's

136 AС Auch в в 5, fols. 403r, 415v.

137 Chevalier, Bonnes villes, 104; Chevalier, 'gouverneurs', 300; Henri Drouot, 'Les pouvoirs d'un gouverneur de Bourgogne au XVI ${ }^{\mathrm{e}}$ siècle', Annales de Bourgogne 9 (1937), 147-52; Potter, Renaissance France at War, 237; Veyrat, 'Gouverneurs de normandie', 564-66.

138 Canel, Histoire de Pont-Audemer, 43.

139 Harding, Power Elite, 31.

140 Vaesen and Charavay, Lettres de Louis XI, iii. 272-73.

141 Zeller, 'Premiers gouverneurs d'Auvergne', 168. 
visit to Clérmont, Louis XI was in conflict with Jean de Bourbon, whose brother Charles had recently been appointed bishop of Clérmont. ${ }^{142}$ By supporting Clérmont's bourgeois in their long struggle against episcopal power, Doyat sought to gain municipal backing for the Crown's efforts to reinforce its power in Auvergne at the expense of the Bourbon family. ${ }^{143}$ Overall, governors' efforts to buttress the power of urban elites against local seigneurial and ecclesiastical lords gave rise to the development of a mutually strengthening relationship between town leaders and the monarch. Yet, as well as bringing benefits for municipal elites, the nature of this relationship also made them ever more dependent on the Crown for their power.

Governors had households which were modelled on that of the king. In the same way that municipal governments found it necessary to enlist the support of royal officials to ensure that the king's grants were ratified, it was also important for civic councils to have the support of those who travelled with the governor. As David Potter has noted (like the monarch) governors were 'expected to take advice from those of his council who travelled with him.'144 Pont-Audemer's échevins offered gifts of money to the key officials in Louis of Orléans' household at his entry in 1492 in order to encourage the duke to receive their requests favourably. ${ }^{145}$ Municipal councils targeted the most powerful and influential members of the governor's household. When Louis de La Trémouille entered Dijon in 1508, the échevins gave substantial gifts to his trumpeters and fourriers. ${ }^{146}$ As we saw in the previous chapter, it was important for municipal councils to construct good relationships with fourriers as they controlled the provision of lodgings in towns. ${ }^{147}$ Trumpeters were also key officials for urban governments because of the influential position they held in noble households. For example, Tournai's échevins paid the dauphin's

142 Olivier Mattéoni, Un prince face à Louis XI: Jean II de Bourbon, une politique en procès (Paris, 2012), 217-92.

143 Doyat was a staunch enemy of the duke of Bourbon, whom he claimed had usurped the king's rights: Dupont-Ferrier, Gallia regia, i. 172.

144 Potter, War and Government, 103. For a governor's household and its networks of influence, see that of Anne de Montmorency, governor of Languedoc: Thierry Rentet, 'Network Mapping: Ties of Fidelity and Dependency among the Major Domestic Officers of Anne de Montmorency', French History 17 (2003), 109-26.

145 Canel, Histoire de Pont-Audemer, 43.

146 Gouvenain, Inventaire sommaire, Dijon, iii. 15.

147 This was also true at governors' entries. See, for example: Aм Narbonne вв 4, fol. 14v; Gouvenain, Inventaire sommaire, Dijon, iii. 15. As with royal entries, the members of governors' entourages could cause trouble with townspeople: AC Auch BB 5, fol. 203 v. 
trumpeter to recommend them to their master in $1410 .{ }^{148}$ An additional incentive for towns to provide gifts to members of governors' entourage was that they often included prominent figures from the king's household. When Anne de Montmorency entered Béziers, he was accompanied by Francis I's maîtres-desrequetes, several members of the royal council and leading financial officers. ${ }^{149}$ Hence, the provision of gifts to those people who travelled with provincial governors allowed urban administrations to form relationships with the key figures in the central administration. These relationships could prove to be especially lucrative when governors' officials were promoted to royal service. ${ }^{150}$

It was particularly important for urban governments to gain the favour of the governor's secretaries as they had to countersign their master's grants in order for them to be valid. ${ }^{151}$ As a consequence of this power, the governor's secretaries received substantial gifts from urban administrations at an entry. When Jacques d'Albon entered Lyon in 1550, the consuls gave his two secretaries (Malatrat and du Tronchet) 40 écus each. ${ }^{152}$ Likewise, Narbonne's rulers provided gifts of 50 écus and luxury sheepskins to the secretaries of Henri de Montmorency, governor of Languedoc, at his inaugural entry in $1563 \cdot{ }^{153}$ The provision of gifts to governors' secretaries could benefit towns for years to come because the tenure of their office was long and they often served consecutive governors. Furthermore, governors' secretaries were in a good position to assist municipal councils with local concerns; indeed, they developed their own networks of clientage with urban elites. When Antoine de Bourbon entered Amiens as the governor of Picardy, the municipal council took particular care to entertain his secretaries so that they 'always have in good recommendation the business of this town.' ${ }^{154}$ At Mary of Guise's entry in 1551, Amiens' échevins apportioned money specifically to entertain the governor of Picardy's secretaries, who were travelling with the queen. ${ }^{155}$ Governors' secretaries had significant fiscal powers, which they could use to assist urban governments. In 1554, Antoine Bouchet, the principal secretary of the governor of Picardy, allocated 12,00o livres to Amiens' municipal council to repair the city's

\footnotetext{
148 Famiglietti, Royal Intrigue, 99.

149 Domarion, Entrée de François I ${ }^{\text {er }}$, Béziers, 40.

150 Michel Antoine, 'Les gouverneurs de province en France (XVI ${ }^{\mathrm{e}}-\mathrm{XVIII}{ }^{\mathrm{e}}$ siècles)', in F. Autrand, ed., Prosopographie et génèse de l'état modern (Paris, 1986), 189-90.

151 Antoine, 'Gouverneurs de province', 189-90.

152 Ам Lyon вв 71, fols. 205r-205v; Péricaud, 'Gouverneurs de Lyon', 24-25.

153 Aм Narbonne в B 1, fol. 25or.

154 AM Amiens CC 139, fol. 143r; Potter, War and Government, 109.

155 Potter, War and Government, 109.
} 
fortifications, in return for which he received a rent of 1,00o livres. ${ }^{156}$ Likewise, Aix-en-Provence's consuls gifted 30 livres to Jean Ragueneau (the principal secretary of Antoine de Savoie, governor of Provence) in September 1500 for having given numerous services on behalf of the town, for which he had not taken any payment. ${ }^{157}$ As these examples show, it was crucial for urban elites to develop good relationships with a governor's officials, particularly the secretaries, as they held considerable administrative and financial powers, which they could use to assist municipal administrations.

In addition to the secretaries, towns also used entries to engage the services of the governor's deputy. As governors were often called away from their provinces by military campaigns or business at court, deputies ruled in their absence. ${ }^{158}$ Consequently, it was important for municipal councils to cultivate friendly relations with these officials. Indeed, it could be particularly beneficial for urban governments to develop networks of clientage with deputy governors as they tended to belong to powerful families at court. ${ }^{159}$ Lieutenants could also be related to the governor and hold influence with him (Jacques d'Albon's cousin was his lieutenant in the Lyonnais). ${ }^{160}$ Moreover, some deputies were promoted to the position of governor. Following the disgrace of Anne de Montmorency in 1541, his deputy, Antoine Desprez de Montpezat, was raised to the governorship of Languedoc. ${ }^{161}$ As the deputy was only the governor's assistant, rather than the king's proxy, he could not claim an entry by right. Nonetheless, it could benefit towns to offer ceremonial receptions to deputy governors, especially as they had the power to grant some requests without having to seek the approval of either the king or the governor. The consuls of Nîmes set aside 200 écus from the municipal budget to provide an entry for Just I de Tournon, count of Roussillon (appointed deputy of the governor of Languedoc in 1514), so that they could offer him a petition seeking exemption

156 Potter, War and Government, 107.

157 Aм Aix-en-Provence Bв 47, fol. 43r.

158 For example, in 1537, the governor of Picardy, François de Montmorency, had to delay his inaugural entries because he was on campaign: Potter, War and Government, 74.

159 Potter, War and Government, 66.

160 Watson, 'Friends at Court', 289.

161 P. Dognon, Les institutions politiques et administratives du pays de Languedoc du $X I I{ }^{e}$ siècle aux guerres de religion (1896), 447; Gaston Zeller, 'L'administration monarchique avant les intendants, parlements et gouverneurs', Revue historique 197 (1947), 203. Montmorency was disgraced in the summer of 1541, though he maintained the governorship of Languedoc until May 1542, when it was given to Montpezat: Knecht, Renaissance France, 176. 
from military quartering (which he granted). ${ }^{162}$ Furthermore, municipal councils offered ceremonial receptions to other royal officials in the provinces, particularly baillis and sénéchaux. ${ }^{163}$ As well as providing urban governments with an opportunity to obtain oaths to uphold civic liberties from these agents of the Crown, the provision of entries to baillis and sénéchaux also allowed civic elites to increase their influence at court. ${ }^{164}$ As André Bossuat has noted, baillis and sénéchaux could perform a mediatory role between the centre and the periphery by promoting municipal affairs at court. ${ }^{165}$ When Antoine Desprez de Montpezat (later governor of Languedoc) was appointed sénéchal of Poitou in 1533, the rulers of Poitiers offered him gifts and a ceremonial reception, 'having consideration of the authority of the said person and of the great access and credit that he has towards the king our lord.'166 In addition, baillis and sénéchaux possessed sufficient local jurisdiction to grant some urban petitions, especially those relating to military concerns. When Charles de Lenoncourt, bailli of Vitry, entered Châlons-en-Champagne in March 1489, the échevins offered him gifts and a petition for a reduction in the number of francs-archers the town was obliged to supply. ${ }^{167}$ Although governors gradually came to

162 AM Nîmes LL 3.

163 For baillis' entries, see: AM Amiens AA 5, fol. 212v; AM Tours AA 4; André Bossuat, $L e$ Bailliage royal de Montferrand (1425-1556) (Paris, 1957), 138. For the entries of sénéchaux, see: AD Tarn 4 EDT CC 162; EDT CC 185, fol. 77r; 4EDT CC 452, fol. 4or.

164 For oaths taken by sénéchaux at entries see: AC Auch AA 1; Auguste, Inventaire sommaire, Agen, 15, 22; E. Prarond, Extraits du Livre Rouge et du Livre Blanc de l'Échevinage. Introduction à quelques parties d'une étude les lois et les moeurs à Abbeville, 1184-1789 (Paris, 1906), 96-97. Furthermore, towns provided gifts to baillis who entered in royal entourages. See, for example, Louis XI's entry into Rouen in 1462: Beaurepaire, Inventaire sommaire, Rouen, 63; Charles vi's into Amiens: Ам Amiens вв 2, fol. 48v. They also provided gifts to baillis who entered in governors' entourages. See the bailli entering with Louis de Brézé: Beaurepaire, Inventaire sommaire, Rouen, 134. A sénéchal could also receive the oath of loyalty on behalf of the king in return for the ruler's confirmation of urban privileges: G. de Lépinay, 'Sénéchaux, vice-sénéchaux et gouverneurs du Limousin', Bulletin de la société scientifique historique et archéologique de la Corrèze 8 (1886), 494.

165 Bossuat, Bailliage royal de Montferrand, 127-47.

166 Municipal deliberations, cited in Rivaud, Villes et le roi, 204.

167 AC Chalons-en-Champagne вв 5, fols. 10or-101r. For the political powers of baillis and sénéchaux see: Alain Demurger, 'Guerre civile et changements du personnel administrative dans le royaume de France de 1400 à 1418: l'exemple des baillis et sénéchaux', Francia 6 (1978), 151-289 (especially 186-201); Gustave Dupont-Ferrier, Les Officiers royaux des bailliages et sénéchaussées et les institutions monarchiques locales en France à la fin du moyen age (Paris, 1902); Bernard Guenée, Tribunaux et gens de justice dans le bailliage de Senlis à la fin du Moyen Âge (vers 1380-vers 1550) (Paris, 1963). 
supplant the baillis and sénéchaux as the principal agents of royal power in the provinces, their local authority led some municipal governments to continue to offer entries to these officials right through to the mid-sixteenth century. ${ }^{168}$ For example, on 28 August 1538 Amiens' échevins prepared a ceremonial entry for Louis III de Bournel, lord of Thiembronne, who had just been appointed bailli. ${ }^{169}$ Occasionally, municipal governments offered ceremonial receptions to the wives of baillis and sénéschaux. In 1533, Nîmes' consuls granted an entry to Jeanne Ricard de Genouillac, wife of the sénéchal of Beaucaire, Charles de Crussol. As well as going out to greet Jeanne in an extramural procession, the consuls sounded the artillery in her honour and offered her gifts of wines and torches. ${ }^{170}$ While her husband's family - as viscounts of Uzès - were powerful local lords, more important for the consuls was the fact that Jeanne's father, Jacques Ricard de Genouillac, was a very powerful man at court and had held the elevated position of grand écuyer from 1526 (he was appointed to the order of Saint Michael in the same year and went on to become governor of Guyenne in 1541 and then governor of Languedoc in 1546). ${ }^{171}$ Nîmes' municipal deliberations note that the consuls accorded Jeanne an entry, not because she was the wife of the sénéchal but because she was a 'great lady of [a] powerful house.'172 Furthermore, as the only heir to her father's lands, Jeanne was a very important person in her own right. ${ }^{173}$ By according an entry to powerful women, municipal administrations sought to harness their strength and tap into their networks of influence for the good of the town.

The actions of Nîmes' consuls were part of a wider move by urban administrations in the sixteenth century to offer entries to the female relations of influential men. Recognising that governors were the new principal agents of royal power in the provinces, urban governments began to grant entries to their wives. Indeed, there was a steady increase in the scale of the honours that

168 For example, the governors of the Limousin were given the powers of the sénéchaux in the late fifteenth century: G. de Lépinay, 'Sénéchaux, vice-sénéchaux et gouverneurs du Limousin', Bulletin de la société scientifique historique et archéologique de la Corrèze 8 (1886), 506-8.

169 Ам Amiens в В 23, fol. 64v; Louis Moréri, Le grand dictionnaire historique ou le mélange curieux de l'histoire sacrée et profrance, 10 vols (Paris, 1759), ii. 429.

170 AM Nîmes LL 5.

171 Robert Knecht, 'Jacques de Genouillac, dit Galiot (v.1465-1546)', in Michon, Conseillers de François $I^{e r},{ }_{155}^{-61 .}$

172 AM Nîmes LL 5 .

173 F. Galabert, Galiot de Genouillac: seigneur d'Assier, grand maître de l'artillerie (Paris, 1901), 38-39. For the career of Jacques Ricard de Genouillac, see: François de Vaux de Foletier, Galiot de Genouillac, maître de l'artillerie de France (1465-1546) (Paris, 1925). 
towns accorded to governors' wives at their ceremonial entries. While Marie de Montauban (wife of Georges de La Trémouille) and Louise de Valentinois (wife of Louis de La Trémouille) entered Dijon with their husbands, Louise de Brézé was the first governor's wife to receive her own greeting from the échevins when she entered the city with her husband, Claude II of Lorraine, in December 1550. ${ }^{174}$ At the duke of Longueville's inaugural entry into Amiens in 1571, the governor's wife entered on her own after him and was given her own greeting and speech outside the city walls (like a royal entry). ${ }^{175}$ Furthermore, governors' wives received expensive gifts at their entries by the mid-sixteenth century. In order to persuade women such as Louise de Brézé to work for their benefit, municipal councils began to offer them the types of gifts customarily presented to queens. When Louis de Gruuthuse made his inaugural entry into Amiens as lieutenant général of Picardy, the échevins spent 200 écus on a golden mask of the head of Saint John the Baptist to present to his wife (the form of gift that was customarily offered to visiting queens), with the deliberations noting that 'he [Louis] always has the business of this said town in recommendation. ${ }^{176}$ In return for gifts, governors' wives (like French queens) offered to the use the influence they had with their husbands to promote urban interests. When Léonor d'Orléans, duke of Longueville, entered Amiens as governor of Picardy in 1571, the échevins presented his wife, Marie de Bourbon, with a statue of the head of John the Baptist. In response, Marie told the échevins that she would never forget the honour the city had given her and offered to speak to her husband on their behalf. ${ }^{177}$ Likewise, when Françoise de Foix-Candale accompanied her husband, Claude de Savoie, at his inaugural entry into Aix-en-Provence as the governor of Provence, she was gifted 160 écus by the consuls, which is especially striking as this gift cost more than the wine the consuls gave to her husband. ${ }^{178}$ As we saw with the provision of gifts of

174 Gouvenain, Inventaire sommaire, Dijon, iii. 15-16; Catherine Chedeau, Les Arts a Dijon au XVI ${ }^{e}$ siècle: les débuts de la Renaissance 1494-1551, 2 vols (Aix-en-Provence, 1999), i. $229-233$.

175 AM Amiens B B 40, fol. 24v.

176 Ам Amiens в в 20, fols. 148r-148v. At Auch, the consuls levied a forced loan of 2,00o livres on the population in 1569 to cover the costs of the reception and gift for Antoinette d'Ysalguier, wife to Blaise de Montluc, lieutenant-général of Guyenne: AC Auch B B 5, fol. 328 r.

177 Ам Amiens вв 40, fol. 23r. According to the municipal deliberations, the échevins gave Marie de Bourbon a copy of the head of Saint John 'so that she remembers the town of Amiens, towards which she has always shown affection': Aм Amiens BB 40, fol. 24r; CC 194, fol. 89r.

178 Aм Aix-en-Provence вв 45, fol. 17r. 
money to chancellors' wives in the last chapter, municipal councils may have adopted this tactic with governors' wives in order to get round the restrictions on gift giving that the Crown was putting into place in the mid-sixteenth century. Furthermore, many of these women were powerful in their own right. By granting gifts to people such as Françoise de Foix-Candale, municipal councils sought to channel their power - not just that of their husbands. When Catherine de Tournoël entered Lyon with her husband, Jacques d'Albon, in August 1550, the consuls gave her two hundred écus in a velvet purse. ${ }^{179}$ While Jacques d'Albon was undoubtedly a powerful figure (and Lyon's town council was then trying to win him over to their cause) Catherine de Tournoël stood to be a great asset to the city in her own right, particularly as she was very close to the queen. This connection to the queen was useful for Lyon's consuls as they were then seeking Catherine de Medici to promote the city's cause with the king.

Some civic governments granted substantial honours to governors' wives specifically to gain their influence rather than that of their husbands. While Antoinette de Bourbon, wife of Claude of Lorraine, governor of Champagne, entered Châlons-en-Champagne at her husband's side in 1524, the échevins granted Antoinette her own ceremonial entry when she returned to the town alone in July $1525 .{ }^{180}$ The honour of being granted an entry without the presence of her husband reflected Antoinette's remarkable ability to promote Châlons' affairs at court. After ceremonially welcoming the duchess on 28 April 1529, the échevins promised her a silver cup if she managed persuade Francis I to abolish the grenier à sel at Vitry. ${ }^{181}$ Antoinette was an effective broker for the échevins, whose relationship with the duchess was lucrative and long lasting. For example, she was able to obtain a tax reduction of 6,00o livres for the town (from 13,00o livres to 7,000 livres). ${ }^{182}$ The échevins rewarded and retained Antoinette's services by granting her regular ceremonial entries; indeed, Châlons provided her with five ceremonial entries by 1531. To put it another way, Antoinette made more ceremonial entries into Châlons than both her husband and the king of France combined. ${ }^{183}$ Although women were barred from holding office, they acted as intermediaries between urban administrations and their male relatives. Furthermore, governors' wives had their own

\footnotetext{
179 Ам Lyon в в 71, fol. 205v.

18o AC Châlons-en-Champagne B B 7, fols. 113r-114r, 116r, 124r, 149r.

181 AC Châlons-en-Champagne в в 7, fol. 22or.

182 AC Châlons-en-Champagne вв 8, fol. 186r.

183 See, for example, her entries in January 1530 and September 1531: AC Châlons-enChampagne вв 7 (1521-1534), fols. 25or, 277r.
} 
networks of influence at court, separate to those of their husbands, which municipal councils tried to access by granting them the honour of a ceremonial entry. By the early the seventeenth century, towns such as Narbonne went so far as to grant a canopy to the governor's wife, even when she made an entry without her husband. ${ }^{184}$ Overall, these women were versatile agents for urban administrations and they employed their services in multiple ways. As the wives of governors, these women were in a favourable position to influence this emerging power elite (in the same way that the queen held influence with her husband as a consequence of her intimate relationship with him). Yet, as we saw, noblewomen were also power brokers in their own right and could be of great value to urban governments. While the governor could be called away to go on campaign or attend court, his wife tended to remain in the region and thus acted a stable pivot of influence and patronage.

The ceremonial entries of provincial governors formed a crucial component in relations between centre and periphery in pre-modern France. Although the governor's status as the king's proxy gave him the right to enter the towns of his province, the standard form of a governor's entry only emerged after decades of negotiations in town halls across the kingdom. Despite an initial vagueness from the Crown about how provincial governors should be welcomed, urban governments considered these men to represent the person of the king and they welcomed them accordingly. Hence, by the mid-sixteenth century, governors' entries mirrored those given to the king. Municipal councils introduced markers of esteem into entries to win the friendship of the governors and obtain their services as brokers. Governors were drawn from the small pool of the kingdom's great families, each of which was trying to expand their fortunes at the expense of their rivals. Urban elites were able to exploit the competition for honours by devising entries that supported a governor's efforts to assert his exalted status. ${ }^{185}$ These marks of esteem signalled to those who witnessed the event (or read reports about it) that the governor was the direct representative of the king and possessed his authority. Urban

184 See, for example, the entry of Marie-Félicie des Ursins (wife to Henri de Montmorency, governor of Languedoc) into Narbonne in December 1618: Aм Narbonne Bв 10, fol. 445r; Harding, Royal Power, 17.

185 For the nobility's competition for honours in sixteenth-century France, see: Stuart Carroll, Blood and Violence in Early Modern France (Oxford, 2006), 49-82. For the pursuit of markers of esteem in political systems, see: Charles Tilly, 'Domination, Resistance, Compliance... Discourse', Sociological Forum 6 (1991), 593-602; Steven Lukes, Power: A Radical View, 2nd edition (Basingstoke, 2005), 10. 
governments used the symbolic language of honour to express the power wielded by the governor, particularly through the granting of a canopy.

As the canopy was one of the principal marks of sovereignty in pre-modern Europe, it was normally reserved for royal entries. There was a competition for the right to a canopy during the early decades of the sixteenth century. Whereas elite royal officers such as the constable tried to assert their right to this mark of honour, urban governments attempted to limit its use. Municipal rulers wanted to retain the power to grant the canopy so that it could be used as leverage to reward and retain their brokers. Governors' entries grew increasingly magnificent during the sixteenth century because French towns used these events to reward governors for their services. As maintaining one's status was expensive (especially at the very highest levels of society), ceremonial entries allowed governors to put some of these costs on the towns of their gouvernements. Whereas previous studies of the networks of clientage developed by the provincial governors of France have largely focused on nonurban groups, governors' municipal clients were also important. The support of these civic leaders became particularly important during the latter decades of the sixteenth century, when some governors challenged the authority of the Crown. ${ }^{186}$

Nonetheless, urban administrations found it difficult to control the form of governors' entries throughout the sixteenth century. Once a precedent for an honour had been set, it could not be reversed. While entries were local events, they also operated within a national system, whereby wider trends spread across the kingdom outwith their control. By the mid-sixteenth century, the use of the canopy had become a standard part of a governor's entry. Overall, there was a steady upturn in the status of governors' entries throughout the sixteenth century; by the 1560 s, towns were employing the language normally reserved for the king at governors' entries. In order to keep rewarding governors for their services, urban governments had to increase the splendour and marks of esteem deployed in their entries. Hence, they started to welcome their wives with increasing ceremony, as this allowed them to both honour to the governor and to utilize his spouse's networks of influence at court. It was important for towns to have the good favour of their governors because they possessed considerable authority over local rights and liberties. ${ }^{187}$ Furthermore, urban

186 Chevalier, 'King's Council', 124. For an overview of the historiography on this topic, see: Elie Haddad, 'Noble Clienteles in France in the Sixteenth and Seventeenth Centuries: A Historiographal approach', French History 20 (2006), 75-109. A notable exception to this focus on non-urban groups is: Konnert, 'Provincial Governors and their Regimes', 823-40.

187 Potter, War and Government, 96-97. 
governments considered governors to have the necessary royal authority to confirm municipal liberties on the king's behalf. In addition to ratifying existing liberties, urban governments used governors' entries to obtain further rights. As well as possessing the power to grant petitions, governors promoted urban requests with the king and his council. As David Potter has observed, governors 'increasingly received or screened deputations from the bonnes villes and thus absorbed part of the petitioning process.'188 Whereas Gaston Zeller posited that there was a decline in governors' powers across the sixteenth century, in fact their powers grew steadily during this period with the increased magnificence of their entries acting as a means to strengthen their position in the kingdom. ${ }^{189}$ Governors' entries became particularly important during Henry III's reign, as the monarch tended to avoid making public entries and had provincial governors act in his place. ${ }^{190}$ In short, as the power and authority of governors increased during the sixteenth century, the scale and pomp of their entries made them increasingly indistinguishable from the king.

188 Potter, Nation State, 120.

189 Zeller, 'Administration monarchique', 201-12; idem, 'Gouverneurs de provinces au XVI e siècle', Revue historique 185 (1939), 225-56.

190 Le Roux, 'Rites of Monarchy', 117. 